TOPICAL REVIEW

Strategies to improve ellagic acid bioavailability:

Recent citations from natural or semisynthetic derivatives to nanotechnological approaches based on

Rifabutin-Loaded Nanostructured Lipid Carriers as a Tool in Oral Anti-

Mycobacterial Treatment of Crohn's

Disease

Helena Rouco et al innovative carriers

To cite this article: Claudia Ceci et al 2020 Nanotechnology 31382001

View the article online for updates and enhancements.

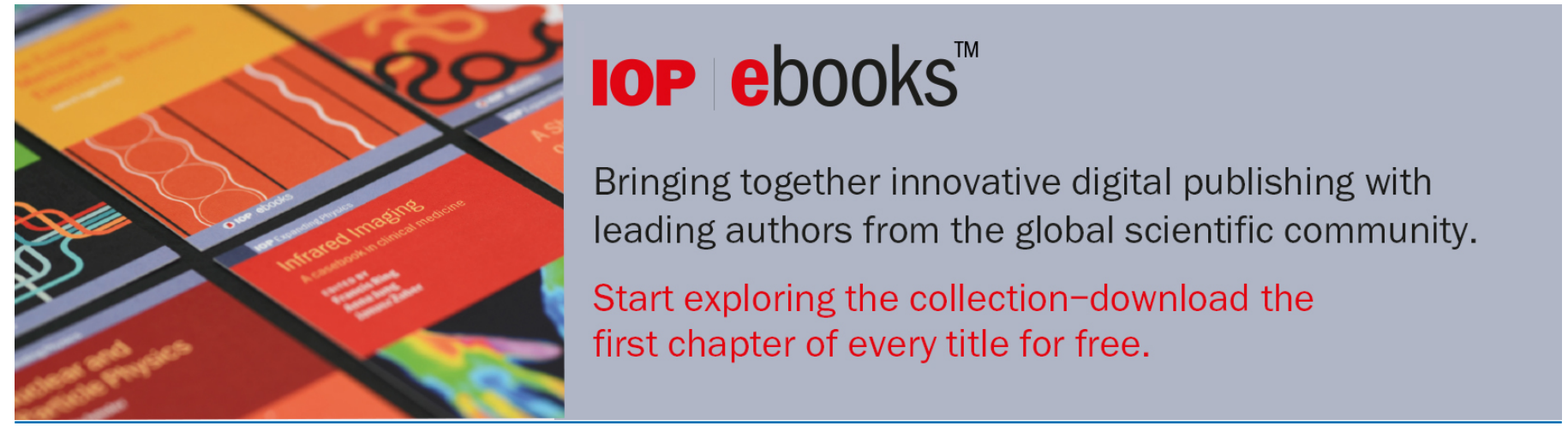

This content was downloaded from IP address 160.80 .58 .33 on 11/11/2020 at 12:35 


\title{
Strategies to improve ellagic acid bioavailability: from natural or semisynthetic derivatives to nanotechnological approaches based on innovative carriers
}

\author{
Claudia Ceci ${ }^{1,3}$, Grazia Graziani ${ }^{1,3}$, Isabella Faraoni ${ }^{1}$ and Ilaria Cacciotti ${ }^{2} \mathbb{C}$ \\ ${ }^{1}$ Department of Systems Medicine, University of Rome Tor Vergata, Via Montpellier 1 00133, Rome, \\ Italy \\ ${ }^{2}$ Department of Engineering, University of Rome 'Niccolò Cusano', INSTM RU, Via Don Carlo Gnocchi \\ 3 00166, Rome, Italy \\ E-mail: ilaria.cacciotti@unicusano.it
}

Received 11 December 2019, revised 11 March 2020

Accepted for publication 7 May 2020

Published 3 July 2020

\begin{abstract}
Ellagic acid (EA) is a polyphenolic compound whose dietary consumption is mainly associated with the intake of red fruits, including pomegranates, strawberries, blackberries, blackcurrants, raspberries, grapes or dried fruits, like walnuts and almonds. A number of studies indicate that EA exerts health-beneficial effects against several chronic pathologies associated with oxidative damage, including different kinds of cancer, cardiovascular and neurodegenerative diseases. Furthermore, EA possesses wound-healing properties, antibacterial and antiviral effects, and acts as a systemic antioxidant. However, clinical applications of this polyphenol have been hampered and prevented by its poor water solubility $\left(9.7 \pm 3.2 \mu \mathrm{g} \mathrm{ml}^{-1}\right.$ in water $)$ and pharmacokinetic profile (limited absorption rate and plasma half-life $<1 \mathrm{~h}$ after ingestion of pomegranate juice), properties due to the chemical nature of the organic heterotetracyclic compound. Little has been reported on efficient strategies to enhance EA poor oral bioavailability, including chemical structure modifications, encapsulation within nano-microspheres to be used as carriers, and molecular dispersion in polymer matrices. In this review we summarize the experimental approaches investigated so far in order to improve EA pharmacokinetics, supporting the hypothesis that enhancement in EA solubility is a feasible route for increasing its oral absorption.
\end{abstract}

Keywords: ellagic acid, bioavailability, polymeric nano- and microspheres, drug delivery, health promotion, cancer, melanoma

(Some figures may appear in colour only in the online journal)

\footnotetext{
3 These authors contributed equally
} 


\section{Introduction}

Ellagic acid (EA) is a polyphenolic flavonoid detected in pomegranates, berries (blackberries, blackcurrants, raspberries, strawberries, grapes) and dried fruits (walnuts, almonds) [1-3], as well as in distilled beverages, like cognac, rum and scotch whisky [4].

Several studies have demonstrated that EA has significant health-beneficial effects against chronic diseases associated with oxidative damage $[5,6]$, including different kinds of cancer [7, 8], cardiovascular diseases [9] and neurodegenerative disorders [10]. Furthermore, EA has wound-healing properties, promoting blood coagulation through the activation of factor XII of the intrinsic cascade [11], as well as antimicrobial or antiviral activities [12-15]. Therefore, EA is regarded as a high-value antioxidant, anti-inflammatory and chemopreventive agent, and it is widely employed in food, cosmetic and pharmaceutical industries [16].

However, some drawbacks associated with the chemical structure of this heterocyclic polyphenol, including both a lipophilic and a hydrophilic portion, like poor water solubility [17], limited oral bioavailability and short plasma half-life, hamper EA clinical applications and strictly limit its potential as a systemic drug. Moreover, even if EA is the main consumed polyphenol, the average individual intake is extremely low (i.e. $343 \mathrm{mg} / \mathrm{year}$ ) and insufficient to achieve the plasma concentrations necessary for specific tumour prevention [18]. Currently, some companies are marketing capsules and tablets containing EA-rich extracts isolated from pomegranates, red raspberries, red raspberry seeds or an Indian plant (T. chebula), or United States Pharmacopeia (USP) grade EA (blended with herb extracts) [19]. Nevertheless, despite the fact that several studies have evaluated the EA clinical potential, its bioavailability has not received much attention [19]. Overcoming EA pharmacokinetic limitations represents a great challenge for the study of its actual beneficial effects. Three main strategies can be followed to fully exploit EA therapeutic potential: (i) use of natural or semisynthetic derivatives; (ii) encapsulation within proper delivery systems able to increase EA solubility, stability and bioavailability; (iii) formulation of molecular dispersions in polymer matrices.

In this review, we provide a complete overview about EA origin, chemistry, health-beneficial properties, applications, and, mainly, the strategies to improve its pharmacokinetics.

\subsection{Origin and chemistry of ellagic acid}

First discovered by the chemist Henri Braconnot in 1831 and first synthesized by heating gallic acid with arsenic acid or silver oxide by Julius Löwe in 1868, EA $(2,3,7,8$ tetrahydroxy[1]-benzopyranol[5,4,3-cde]benzopyran-5,10-

dione; $\mathrm{MW}=302 \mathrm{~g} \cdot \mathrm{mol}^{-1}$ ) is a naturally occurring compound [20] which belongs to the ellagitannins (ETs) family. The ETs, together with gallotannins (GTs), constitute the family of hydrolyzable tannins (HTs), highly studied phytochemicals because of their role in the health-promoting effects of pomegranate juice and extract, which have gained considerable attention in recent decades. The HTs are classified as ETs and GTs according to the phenolic acids esterified to the core cyclic polyol molecule, which is often a glucose; in total, more than 60 HTs have been detected from pomegranate by mass spectrometry and/or nuclear magnetic resonance [21].

From a chemical point of view, EA is a dimer of gallic acid, characterized by four fused rings (two of which are lactones) and four hydroxyl groups (figure 1). Due to its chemical structure, EA has both lipophilic (6-member hydrocarbon rings) and hydrophilic (hydroxyl groups and lactone rings) properties [22]. Its unique structure renders EA able to accept electrons from various donors, thus contributing to different antioxidant redox reactions [23]. Moreover, EA can be naturally present as free, glycosylated and/or acylated compounds, or as hydrolyzable ET polymers, usually esterified with glucose. Macroscopically, this odourless weak acid exists in the form of cream-coloured needles or yellow powder [24].

The chemical nature of EA accounts for its poor solubility $\left(9.7 \pm 3.2 \mu \mathrm{g} \mathrm{ml}^{-1}\right.$ in water and $33.1 \pm 15.5 \mu \mathrm{g} \mathrm{ml}^{-1}$ in phosphate buffer at $\mathrm{pH}$ 7.4) [17] and for its low bioavailability after oral ingestion. In a study in which ACI rats received black raspberry powder ( $5 \% \mathrm{w} / \mathrm{w}$, corresponding to $\left.75 \mathrm{mg} \mathrm{l}^{-1} \mathrm{EA}\right)$ in their diet, EA oral absorption was around $0.2 \%$ of the administered dose, as assessed through analysis of plasma samples by solvent extractions and HPLC [25]. Similar pharmacokinetic studies performed in humans confirmed that the rate of oral EA absorption was $<1 \%$, after ingestion of pomegranate juice or freeze-dried black raspberries [26, 27].

Metabolism by the gastrointestinal microbiota further reduces the EA absorption rate [26, 28]. The family of microbial metabolites obtained from EA is called urolithins (figure 1): opening of a lactone ring and elimination of a carboxyl group lead to the generation of urolithinD, which in turn is further metabolized to generate urolithinC, A and $\mathrm{B}$, by removal of 1,2 , or 3 hydroxyl groups, respectively $[29,30]$.

Urolithins have a higher absorption rate, likely because of their more lipophilic nature, and result 25-80-fold more bioavailable than EA [31]. Therefore, the health-beneficial effects of EA-containing products are likely due to these derived ETs-catabolites [32, 33], which, once absorbed, can reach different body compartments. Actually, urolithins represent the first natural evidence of the possibility of improving EA solubility, bioavailability and beneficial activity on human health through its chemical manipulation.

\subsection{Biological properties and clinical applications of ellagic acid}

Both EA and ETs have shown antioxidant, anti-inflammatory, and anti-carcinogenic effects in animal and human models, suggesting a potential preventive/therapeutic role for cancer and chronic diseases (figure 2) [8, 9, 34].

EA antioxidant activity can be considered comparable to that of well-known essential vitamins, like ascorbic acid and $\alpha$-tocopherol [35], and more efficient against reactive oxygen 


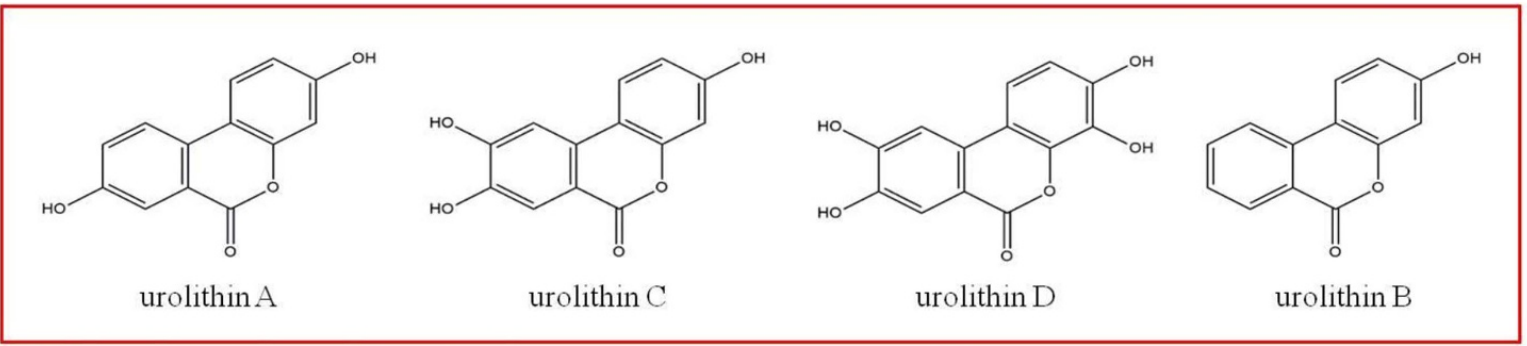

Ellagic acid gut bacterial metabolites<smiles>O=c1oc2c(O)c(O)cc3c(=O)oc4c(O)c(O)cc1c4c23</smiles>

Ellagic acid

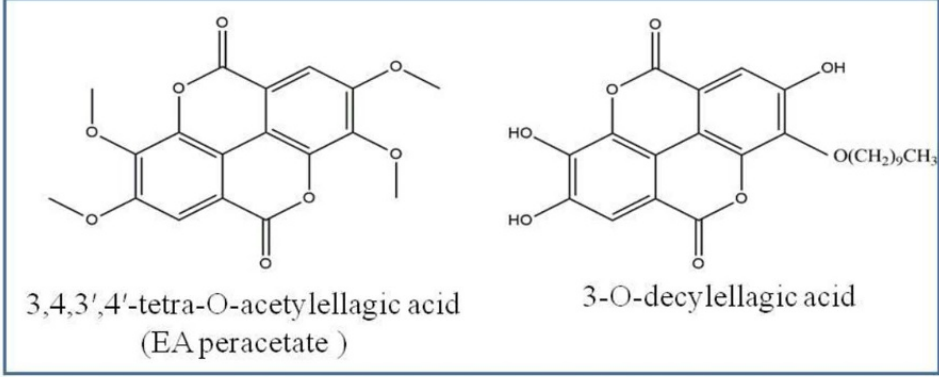

Ellagic acid semisynthetic derivatives<smiles></smiles>

3,3'-di-O-methylellagic acid $\left(3,3^{\prime}-\mathrm{DiOMEA}\right)$<smiles>COc1cc2c(=O)oc3c(O)c(OC)cc4c(=O)oc(c1O)c2c34</smiles>

4,4'-di-O-methylellagic acid $(4,4$ '-DiOMEA)

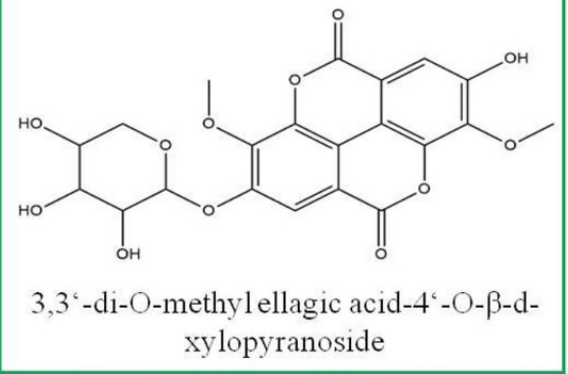

Ellagic acid natural derivatives

Figure 1. Molecular structure of ellagic acid (EA), intestinal metabolites (urolithins) and natural or semisynthetic derivatives, which gained attention in studies aimed at testing their potential health-promoting effects.

species (ROS) than reactive nitrogen species [36]. Furthermore, phenolic compounds like EA are able to hinder the prooxidative action of metals (copper, iron, nickel, cadmium) by chelation $[37,38]$ and directly interact with DNA causing a significant decrease of 8-oxo-2-deoxyguanosine levels, a typical marker of oxidative DNA damage [39-41]. Finally, it has been demonstrated that EA increases the expression/activity of the antioxidant enzymes superoxide dismutase (SOD1), glutathione peroxidase (GPX1), glutathione reductase (GR) and catalase (CAT) [42] and a role has been postulated for EA in the treatment of cirrhosis induced by chemical agents, like carbon tetrachloride [43].

EA anti-inflammatory activity supports its therapeutic potential against many chronic inflammatory diseases, like contact dermatitis and pancreatitis [44, 45]. EA has also been found to prevent activation and function of pancreatic stellate cells (a crucial cell type involved in pancreatic fibrosis) [46], to reduce the pro-inflammatory cytokine IL6 expression and to increase the anti-inflammatory cytokine IL-10 levels in the bronchoalveolar lavage fluids of acidinduced acute lung injury models [47]. The transcription factor $\mathrm{NF}-\mathrm{kB}$, which plays a central role in inflammation and immunity, has been considered a potential target of EA anti-inflammatory effects, as demonstrated in a murine ulcerative colitis experimental model, where the polyphenol was included in the normal diet $(0.5 \%)$ [48]. Other studies have also confirmed the involvement of NF- $\mathrm{kB}$ modulation in EA ability to decrease the serum levels of several pro-inflammatory cytokines [49-52]. Furthermore, EA modulates the expression of cyclooxygenase-2 (COX-2), a proinflammatory enzyme whose gene transcription is controlled by NF- $\mathrm{BB}$ [53], and binds with the high-affinity COX-2 active site [54], thus directly inhibiting its enzymatic activity (i.e. the synthesis of pro-inflammatory prostaglandins). Moreover, EA 


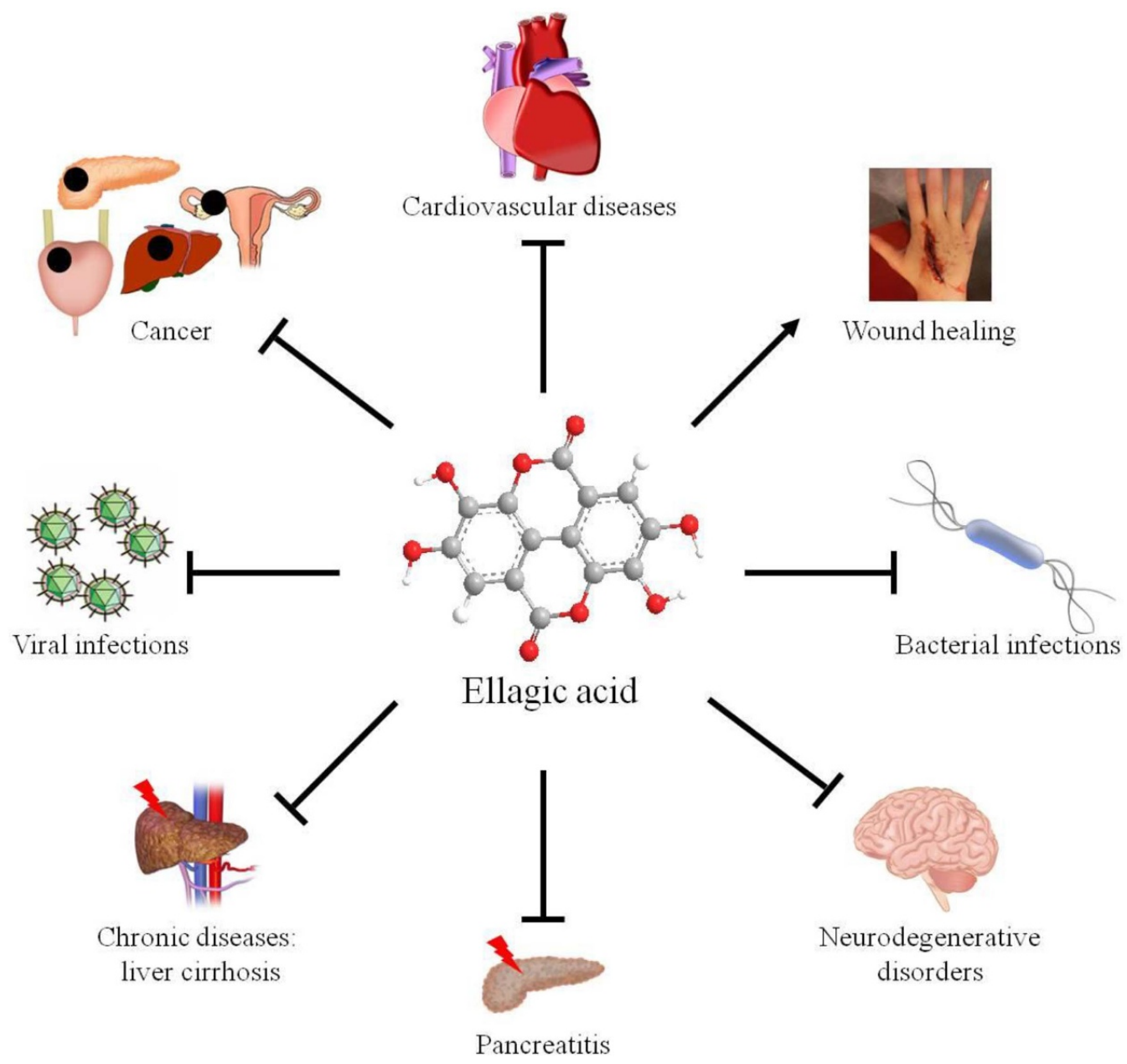

Figure 2. Potential clinical applications of EA: arrow indicates the promotion of a physiological process; horizontal bars indicate the inhibition of pathological conditions.

has been shown to inhibit the expression of vascular cell adhesion molecule 1 (VCAM1), intercellular adhesion molecule 1 (ICAM1) [55] and endothelial leucocyte adhesion molecule (E-selectin) [56], proteins which are required for the adhesion of circulating leukocytes to the vascular endothelium, a crucial step for white blood cell extravasation during the inflammatory response.

Finally, EA is considered as a promising chemopreventive and/or chemotherapeutic compound, since it is able to exert a significant antitumour effect against prostate, colon, pancreas, breast, ovarian and bladder cancers, lymphoma, hepatocellular carcinoma and glioblastoma [8]. Several mechanisms contribute to the antitumour activity of EA, including inhibition of cell proliferation, angiogenesis and extracellular matrix invasion, induction of caspase-dependent apoptosis and modulation of other processes required for tumour formation, progression and metastasis.

Interestingly, EA applications in the cosmetic sector have been reported, by producing a self-assembled supramolecular system based on green-synthetized gold nanoparticles (AuNPs), obtained by using Punica granatum juice for EA adsorption on their surface and chitosan (CS) as a wrapping agent [57]. High antioxidant [around $80 \%$ and
$60 \%$ from the DPPH (2,2-diphenyl-1-picrylhydrazylhydrate) and ABTS (2,2'-azino-bis(3-ethylbenzothiazoline-6-sulfonic acid)) assays, respectively], skin lightening (tyrosinase inhibition of around 50\%) and sunscreen (Sun Protection Factor of 20) properties were demonstrated, suggesting potentially promising applications in the cosmetic and biomedical fields for the obtained system.

\section{Strategies to overcome ellagic acid limitations}

Due to its extremely low water solubility $\left(<10 \mu \mathrm{g} \mathrm{ml}^{-1}\right)$, oral bioavailability and intestinal permeability $\left(0.13 \times 10^{-6}\right)$, EA is categorized as a class IV drug of the biopharmaceutical classification system $[17,58]$. The scarce solubility of EA derives from its high crystallinity degree (it is highly thermostable and its melting point is more than $300{ }^{\circ} \mathrm{C}$ ), and, in particular, from its planar and symmetrical crystalline structure, with an extensive hydrogen-bonding [59]. Therefore, EA is soluble in dimethyl sulphoxide (DMSO), N-methyl pyrrolidone (NMP), pyridine, polyethylene glycol 200 (PEG200), polyethylene glycol 400 (PEG400) and triethanolamine, but it is difficult to solubilize in water as well as in organic 
solvents like methanol $\left(\sim 671 \mu \mathrm{g} \mathrm{ml}^{-1}\right)$, which is a prerequisite for a pharmaceutical entity to be formulated into a dosage form [17].

With respect to its pharmacokinetic properties, EA is poorly absorbed after oral administration, and primary absorption takes place in the stomach and upper small intestine. Rapid elimination of the absorbed compound is due to a marked first-pass metabolism and low enterohepatic recirculation [60], finally resulting in a short plasma half-life and in the achievement of therapeutically irrelevant tissue concentrations [61]. In Sprague-Dawley rats treated orally with EA $\left(50 \mathrm{mg} \mathrm{kg}^{-1}\right)$, plasma levels peaked at about $30 \mathrm{~min}$, with a $\mathrm{C}_{\max }$ of $93.6 \mathrm{ng} \mathrm{ml}^{-1}$. The area under the curve (AUC, which measures the drug concentration in the systemic circulation as a function of time) was $457.2 \mathrm{ng} \mathrm{ml}^{-1} \times \mathrm{h}$, indicating a poor absorption [62]. In human healthy volunteers receiving oral administration of black raspberries $\left(45 \mathrm{~g} \mathrm{day}^{-1}\right.$ for 7 days), the maximal EA concentration in plasma was reached at 1$2 \mathrm{~h}$, while in the urine it appeared within $4 \mathrm{~h}$ after ingestion; overall, less than $1 \%$ was absorbed [63]. Unabsorbed EA is converted to urolithins by intestinal metabolism [29], whereas absorbed EA is metabolized in the liver to methyl esters, dimethyl esters and glucuronides, which are removed by the kidney $1-5 \mathrm{~h}$ after absorption $[64,65]$.

The unfavourable pharmacokinetic properties of EA make it difficult to translate the therapeutic potential of EA-based drugs into an effective clinical treatment. With the purpose of finding suitable strategies to overcome EA pharmacokinetics and to increase EA bioavailability, different approaches can be pursued:

(1) use of natural or semisynthetic derivatives;

(2) development of drug delivery systems to vehiculate EA;

(3) formulation of molecular dispersions in polymer matrices.

\subsection{Ellagic acid derivatives}

From the 1980s to date, several studies focusing on the beneficial properties of natural and semisynthetic EA derivatives (see figure 1) have been published, with the aim of identifying the structural modifications that might result in the improvement of the absorption rate following oral administration.

Initial information in such a context derived from a study in which the effects of EA and some of its more lipophilic derivatives were tested, concerning their influence on the mutagenicity of $( \pm)-7 \beta, 8 \alpha$-di-hydroxy- $9 \alpha 10 \alpha$ epoxy-7,8,9,10-etrahydrobenz[a]pyrene in a Salmonella typhimurium strain. As a result, EA, 3,3'-di- $O$-methylellagic acid (3,3'-DiOMEA), 4,4'-di- $O$-methylellagic acid $\left(4,4^{\prime}\right.$ DiOMEA) and 3-O-decylellagic acid demonstrated similar anti-mutagenic effects [66]. These findings suggest that it is possible to deduce qualitative rules for predicting the activity of EA analogues, taking into account their chemical differences from the parental compound [67]. Conversely, two other semisynthetic derivatives, such as 3,3'-di-beta-Dglucopyranosylellagic acid decaacetate and 3,3'-di-n-octyl$4,4^{\prime}$-dihexanoylellagic acid, were less effective than EA in inhibiting lung tumour formation after exposure of $\mathrm{A} / \mathrm{J}$ mice to benzo[a]pyrene [68]. Interestingly, the peracetate derivative (3,4,3,4-tetra- $O$-acetylellagic acid) was more efficient than EA in protecting bone marrow and lungs from genotoxicity induced by aflatoxin $B_{1}$ [69]. The same compound significantly suppressed melanoma growth and exerted immunostimulating effects in syngeneic C7BL/6 mice in vivo, to a higher extent than EA. Moreover, it induced apoptotic cell death through BCL-2 down-regulation in vitro in B16 melanoma cells. Unfortunately, EA peracetate still maintains poor water solubility [70].

$3,3^{\prime}$-di- $O$-methylEA- $4^{\prime}-O-\beta$-d-xylopyranoside, a natural EA derivative obtained from the acetone extract of the Chinese traditional herb Euphorbia hylonoma (Euphorbiaceae), was found to arrest the cell cycle in the G0/G1 phase, trigger apoptosis and inhibit extracellular matrix invasion in HepG2 human hepatocellular carcinoma cells [71].

Other studies have evaluated EA in vivo metabolites to elucidate possible structure-activity relationships potentially involved in their antiproliferative effects on tumour cells. All urolithins exerted antiproliferative activity on a panel of colon cancer cell lines, although with different potency (urolithinA $>$ urolithinC $>$ urolithinD $>$ urolithinB) [72]. Interestingly, the only differential hydroxyl substitution of urolithinA and urolithinB led to a markedly different antiproliferative activity, suggesting that the additional- $\mathrm{OH}$ at position 8 in urolithinA is crucial for its biological activity. Consistently, another study demonstrated that the presence of a- $\mathrm{OH}$ group at the position 8 , but not at the position 3 , favours the interaction with the drug efflux transporter/breast cancer resistance protein ABCG2/BCRP [73]. On the other hand, considering that urolithins are produced by the opening and decarboxylation of one of the EA lactone rings and that urolithinA is more active than both EA and 3,3'-DiOMEA, the lactone ring seems to be not essential for the antiproliferative activity. Instead, the DiOMEA derivatives have a methoxy group in place of an alcohol group of EA, resulting in decreased molecular polarity [74]. The $4,4^{\prime}$-DiOMEA was the most effective compound in inhibiting colon cancer cell growth, compared to the $3,3^{\prime}$ derivative [74]. This observation further supported the pivotal role of the-OH groups in the $4,4^{\prime}$ positions, providing another rule for the structure-based drug design of EA derivatives with enhanced anticancer activity. Moreover, 4,4' -DiOMEA inhibited the proliferation of a colon cancer cell line resistant to 5-fluorouracil (SW-620-5FuR), with marginal activity against normal cells. In conclusion, the structural modifications of EA to obtain $4,4^{\prime}$-DiOMEA represent promising strategies for the development of new EA-based anticancer drugs with improved antitumour effects [74].

\subsection{Nanoparticle-based approaches for EA bioavailability enhancement}

Recently, several micro- and nanodevices have gained attention as promising drug delivery systems aimed at enhancing drug bioavailability [75, 76] (figure 3).

These specific drug delivery systems represent a nanotechnology-based approach involving biocompatible materials, mainly biopolymers [77]. In detail, different 


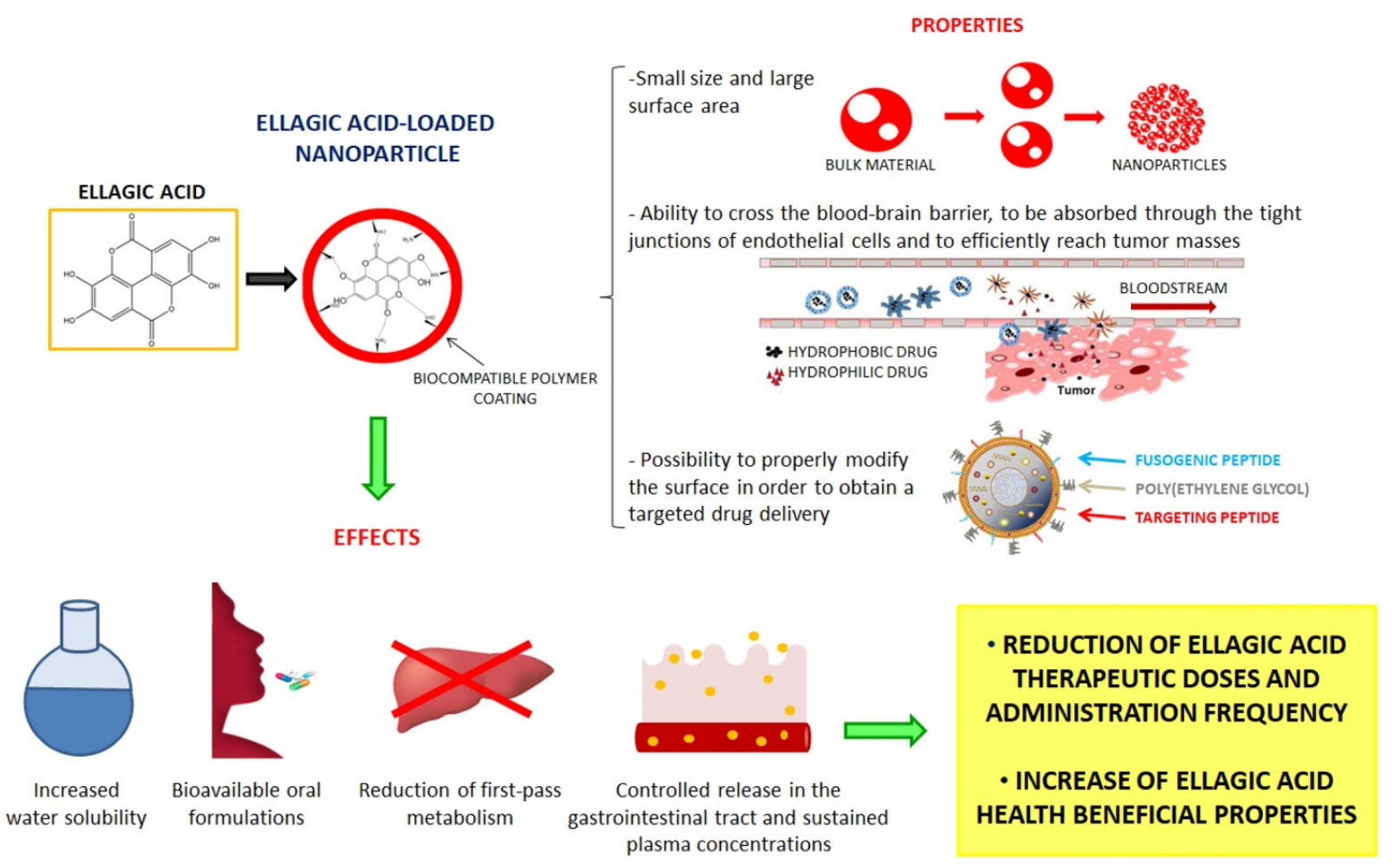

Figure 3. Correlation between the EA encapsulating nanoparticles properties, the enhancement of EA water solubility, and the improvement of its pharmacokinetic profile.

biocompatible polymers have been used in formulations aimed at increasing patient adherence [78, 79], for example by covering unpleasant tastes and odours. Furthermore, specific systems can be designed to achieve targeted drug release and control the active principle local release in the gastrointestinal tract.

Up to now, several EA micro- or nanoparticulate systems have been proposed, including microspheres [80-82], nanoparticles [83-88], pH-dependent microassemblies [89], nano-sized metalla-cages [90], zinc layered hydroxide nanohybrid [91] and nanogels [92], following different procedures such as emulsion-diffusion-evaporation [85, 86, 93], spray drying [62], co-precipitation [62], rotary evaporation [62] and ionic gelation [84] (figure 3).

In particular, many studies were aimed at developing drug delivery systems to achieve therapeutically relevant concentrations of EA in the bloodstream and potentiate its anticancer activity. Polymer-based nanoparticles, human bovine serum albumin-EA complexes encapsulated into thermosensitive liposomes [94], complexes with cyclodextrins [95], encapsulation within niosomes [96], and nano-sized metalla cages [90], molecular dispersion within dendrimers [97] are examples of drug delivery systems developed to reach these desirable goals [90, 95, 98] (figure 4).

\subsubsection{Encapsulation within polymeric spheres Biopoly-} mers have attracted great interest in the field of food and drug delivery systems, in particular for the preparation of micro-/nanocarriers [99, 100] aimed at increasing drug bioavailability [101], thanks to their specific uptake mechanism. Indeed, these devices are able to be taken up in the systemic circulation from the gastrointestinal tract by transcytosis [102] and to prevent the degradation and first-pass metabolism of the encapsulated drugs [78, 103]. In addition, they are able to sustain drug release in the plasma for longer time periods, thus allowing less frequent administration and reduction of potential drug side effects.

Among the several available biopolymers, CS and poly(d,1lactic-co-glycolic acid) (PLGA) were widely employed for EA delivery (table 1).

Several studies reported encapsulation of EA within CS nanoparticles by ionotropic gelation. Spherical nanoparticles (average diameter size of $176 \mathrm{~nm}$ ), with a drug-encapsulation efficacy of $94 \pm 1.0 \%$ and a loading-efficiency of $33 \pm 2.1 \%$, were obtained [84]. The same authors observed a sustained release of EA from the nanoparticles and cytotoxic effects against the KB human oral epidermal cancer cell line, with very low $\mathrm{IC}_{50}$ values compared to free EA. In another study, EA-loaded CS nanoparticles induced rapid blood coagulation and clot retraction, suggesting a possible use as an effective anti-haemorrhagic system [104]. Moreover, similar nanoparticles inhibited hamster buccal pouch tumourigenesis induced by 7,12-dimethylbenz(a)anthracene (DMBA). This effect was attributed to the activation of both intrinsic and extrinsic apoptotic pathways, as a consequence of a sustained delivery of EA molecules [105].

In addition to CS, also chitin (Ch) and schizophyllan (SPG) were used to encapsulate EA [106]. The obtained Ch and SPG particles were characterized by a loading capacity of $79.52 \%$ and $30.08 \%$, an average size of $39.82 \mathrm{~nm}$ and $217.8 \mathrm{~nm}$ and zeta potentials of $-9.14 \mathrm{mV}$ and $+27 \mathrm{mV}$, respectively. EA release from both EA/SPG-NPs and EA/Ch-NPs 


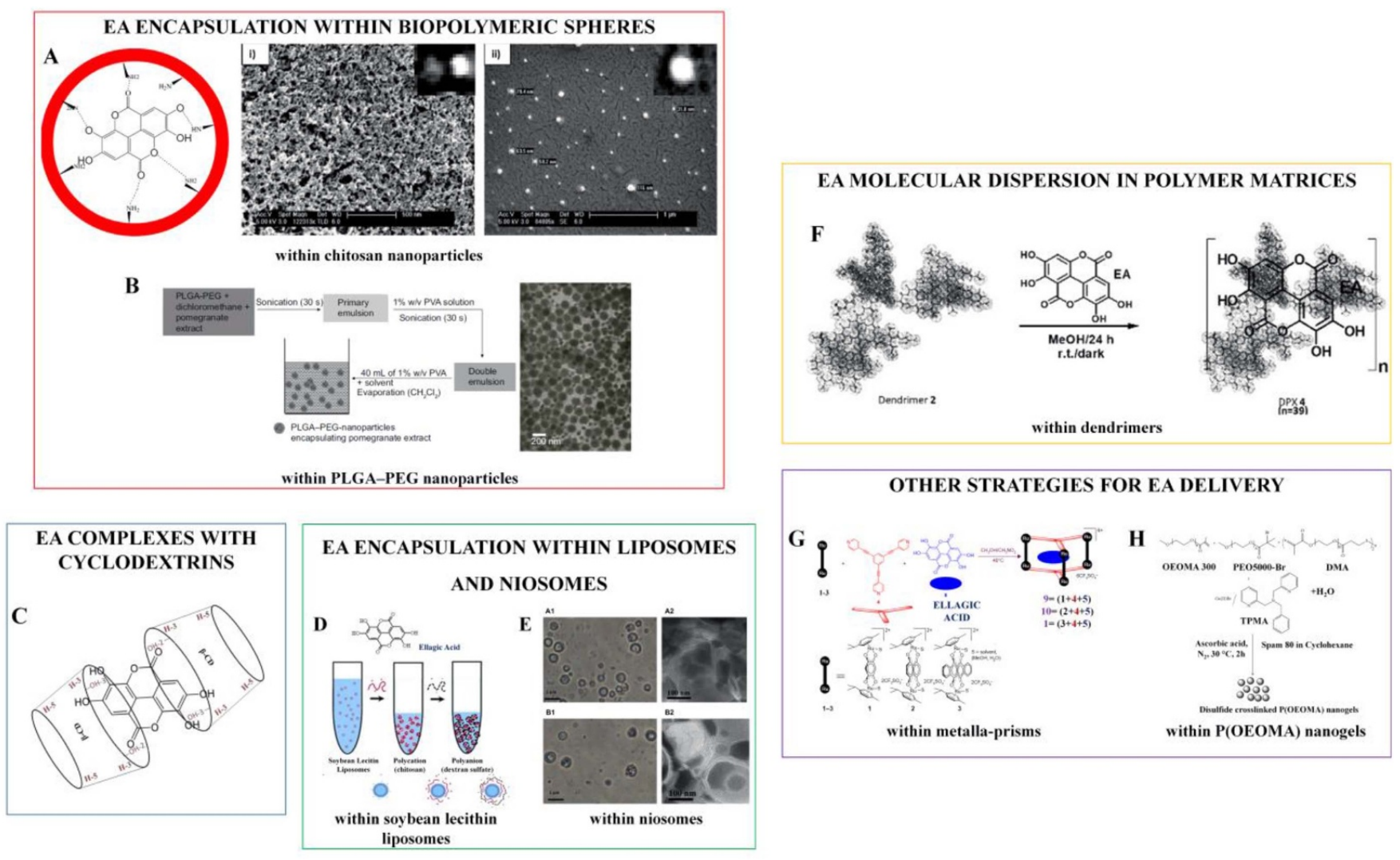

Figure 4. Possible EA carrier strategies. (A) EA encapsulation within CS nanoparticles; (B) EA encapsulation within PLGA-PEG nanoparticles; (C) EA inclusion within cyclodextrins; (D) EA encapsulation within soybean lecithin liposomes coated with biopolymers via layer-by-layer electrostatic deposition; (E) photomicrographs of EA-loaded niosomes containing 15\% v/v PEG and 10\% v/v DMSO (A1, A2) or $1 \%$ v/v NMP (B1, B2) ((A1, B1) acquired by optical microscope and (A2, B2) acquired by transmission electron microscopy); (F) EA molecular dispersion within dendrimers; $(\mathrm{G})$ EA encapsulation within metalla prisma; $(\mathrm{H})$ schematic representation of the synthesis of poly(oligo(ethylene oxide) methyl ether methacrylate) (P(OEOMA)) nanogels via inverse miniemulsion generated by atom transfer radical polymerization (ATRP). (A) Reprinted from [84], Copyright (2013), with permission from Elsevier. (B) Reproduced from [88]. CC BY 3.0. (C) Reprinted from [95], Copyright (2016), with permission from Elsevier. (D) Reprinted from [19], Copyright (2010), with permission from Elsevier. (E) Reproduced from [96]. CC BY 3.0. (F) Reproduced from [97] with permission of The Royal Society of Chemistry. (G) Reproduced from [90]. CC BY 3.0. (H) Reproduced from [92]. CC BY 3.0.

was higher in $96 \%$ ethanol than in different digestive system media ( $\mathrm{pH}$ range 1.5-7.4). As expected, free EA presented greater scavenging activity compared to both EA/SPG-NP and EA/Ch-NP. However, EA/Ch-NPs showed higher activity than free EA at pH 7.4, whereas EA and EA/SPG-NPs scavenging activities decreased by raising the $\mathrm{pH}$ of the media. EA-loaded Ch and SPG NPs also inhibited the proliferation of MCF-7 breast cancer cells with $\mathrm{IC}_{50}$ values of $115 \mu \mathrm{g} \mathrm{ml}^{-1}$ and $60 \mu \mathrm{g} \mathrm{ml}^{-1}$, respectively.

Another low-cost polysaccharide, karaya gum (KG), was used to encapsulate pomegranate-derived EA by the spray drying method. This application of KG was suggested by its complex and branched structure, emulsifier action, cohesive and adhesive properties. The obtained microcapsules (size between 1.69 and $4.55 \mu \mathrm{m}$ ) allowed to envisage potential applications in the food and pharmaceutical sectors [107].

Several studies were carried out to address the design and realization of PLGA particles loaded with EA [83, 86, 87, 93]. In an initial study, EA-loaded PLGA nanoparticles for oral administration were produced by emulsion-diffusionevaporation, using PEG400 as a co-solvent to solubilize the drug and three different stabilizers [polyvinyl alcohol (PVA), didodecyldimethylammonium bromide (DMAB) and a mixture of PVA-CS in different relative ratios] [83]. The highest encapsulation efficiency $(67.49 \% \mathrm{w} / \mathrm{w})$ was obtained using PVA-CS 70:30, with average particle size of $500 \mathrm{~nm}$, while the lowest encapsulation efficiency $(41.73 \%)$ was revealed using DMAB. In detail, concerning the different PVA-CS ratios, it was observed that the zeta potential and the particle size increased with the CS amount, whereas the drug encapsulation efficiency decreased using PVA-CS 50:50. Since a better drug release can be obtained by using carriers characterized by low dimensions and high encapsulation efficiency, the PVA-CS 80:20 was identified as the optimal ratio to obtain a carrier that could allow the study of the influence of different initial drug loading amounts. A decrement of the drug encapsulation efficiency, associated to an increase of the particle size, was revealed with the increment of the initial drug loading from 5 to $15 \%$. Successively, the same authors [93] produced EA-loaded nanoparticles using, in addition to DMAB, PVA/PVA-CS mixtures, and the same CS as a stabilizer. The use of DMAB as a stabilizer made it possible 
Table 1. EA carrier systems: production process, physicochemical properties and biological effects.

\begin{tabular}{|c|c|c|c|c|c|c|}
\hline & $\begin{array}{l}\text { EA delivery } \\
\text { system }\end{array}$ & Production process & $\begin{array}{l}\text { Physico-chemical } \\
\text { properties }\end{array}$ & $\begin{array}{l}\text { Experimental } \\
\text { model }\end{array}$ & Biological effect & Ref. \\
\hline \multirow[t]{6}{*}{$\begin{array}{l}\text { Poly-saccharides } \\
\text { based systems }\end{array}$} & \multirow[t]{3}{*}{ CS nanoparticles } & \multirow[t]{3}{*}{ Ionotropic gelation } & \multirow{3}{*}{$\begin{array}{l}\text {-Good drug- } \\
\text { encapsulation and } \\
\text { loading-efficiency } \\
\text {-Sustained drug } \\
\text { release } \\
\text {-Initial rapid release } \\
\text { of EA from chitosan } \\
\text { matrix }\end{array}$} & $\begin{array}{l}\text { Human oral epi- } \\
\text { dermal carcinoma } \\
\text { cell line }(\mathrm{KB})\end{array}$ & $\begin{array}{l}\text { Anti-proliferative } \\
\text { and pro-apoptotic } \\
\text { activity }\end{array}$ & {$[84]$} \\
\hline & & & & $\begin{array}{l}\text { Fresh whole rat } \\
\text { blood }\end{array}$ & $\begin{array}{l}\text { Anti-haemorrhagic } \\
\text { activity }\end{array}$ & [104] \\
\hline & & & & $\begin{array}{l}\text { DMBA-induced } \\
\text { hamster buccal } \\
\text { pouch oncogenesis } \\
\text { model }\end{array}$ & $\begin{array}{l}\text { Inhibition of } \\
\text { tumour progres- } \\
\text { sion by apoptosis } \\
\text { induction }\end{array}$ & [105] \\
\hline & Ch nanofibers & $\begin{array}{l}\text { Mixing and refri- } \\
\text { geration }\end{array}$ & $\begin{array}{l}\text {-EA loading capacity } \\
\text { of } 79.52 \% \\
\text {-Average size } \\
\text { of } 39.82 \mathrm{~nm} \\
\text {-Zeta potential of } \\
-9.14 \mathrm{mV} \\
\text {-EA release higher } \\
\text { in } 96 \% \text { ethanol than } \\
\text { in different digestive } \\
\text { system media (pH } \\
\text { range } 1.5-7.4) \\
\text {-Lower scavenging } \\
\text { activity than free EA, } \\
\text { except at pH } 7.4\end{array}$ & $\begin{array}{l}\text { Human MCF-7 } \\
\text { breast cancer cells }\end{array}$ & $\begin{array}{l}\text { Growth inhib- } \\
\text { ition }\left(\mathrm{IC}_{50}\right. \\
\left.115 \mu \mathrm{g} \mathrm{ml}^{-1}\right)\end{array}$ & [106] \\
\hline & KG microcapsules & Spray drying & $\begin{array}{l}\text {-Size between } 1.69 \\
\text { and } 4.55 \mu \mathrm{m}\end{array}$ & - & - & [106] \\
\hline & SPG nanoparticles & $\begin{array}{l}\text { Inverse emul- } \\
\text { sion (water-in-oil } \\
(\mathrm{w} / \mathrm{o}) \text { ) method }\end{array}$ & $\begin{array}{l}\text {-EA loading capacity } \\
\text { of } 30.08 \% \\
\text {-Average size of } \\
217.8 \mathrm{~nm} \\
\text {-Zeta potentials of } \\
+27 \mathrm{mV} \\
\text {-EA release higher } \\
\text { in } 96 \% \text { ethanol than } \\
\text { in different digestive } \\
\text { system media (pH } \\
\text { range } 1.5-7.4) \\
\text {-Decrease of EA } \\
\text { and EA/SPG-NP } \\
\text { scavenging activities } \\
\text { by increasing pH }\end{array}$ & $\begin{array}{l}\text { Human MCF-7 } \\
\text { breast cancer cells }\end{array}$ & $\begin{array}{l}\text { Growth inhibition } \\
\left(\mathrm{IC}_{50}: 60 \mu \mathrm{g} \mathrm{ml}^{-1}\right)\end{array}$ & [107] \\
\hline $\begin{array}{l}\text { Polyesters based } \\
\text { systems }\end{array}$ & $\begin{array}{l}\text { PLGA nano- } \\
\text { particles }\end{array}$ & $\begin{array}{l}\text { Emulsion- } \\
\text { diffusion- } \\
\text { evaporation tech- } \\
\text { nique }\end{array}$ & $\begin{array}{l}\text {-Spherical and } \\
\text { homogeneous nan- } \\
\text { oparticles } \\
\text {-High encapsulation } \\
\text { efficiency } \\
\text {-Influence of the } \\
\text { used stabilizer on the } \\
\text { particle size, encap- } \\
\text { sulation efficiency } \\
\text { and zeta potential } \\
\text {-Decrement of the } \\
\text { drug encapsulation } \\
\text { efficiency, associated } \\
\text { to an increase of the } \\
\text { particle size and size } \\
\text { distribution }\end{array}$ & A cell free system & - & [83] \\
\hline
\end{tabular}


Table 1. (Continued)

EA delivery system Production process Physico-chemical prop- Experimental model Biological effect erties

PCL nanoparticles

Emulsion-diffusionevaporation technique

NIPAAm-PEG acrylate polym based systems

$\begin{aligned} \text { PLGA nanoparticles } & \text { Emulsion-diffusion- } \\ & \text { evaporation tech- } \\ & \text { nique }\end{aligned}$
nique
PLGA and PCL nanoparticles
PLGA nanoparticles with the co-encapsulation of EA and coenzyme $\mathrm{Q}_{10}\left(\mathrm{CoQ}_{10}\right)$
NIPAAm-PEG Membrane dialysis -Particle size between
-Different dimension and zeta potential on the basis of the used stabilizer

-Rapid initial release of

EA -Successive slower sustained release

-Release rate increment in the following order: PVA $>$ PVA$\mathrm{CS}>\mathrm{DMAB}$, on the basis of the used stabilizer

Emulsion-diffusion- -Influence of the used evaporation technique

Emulsion technique stabilizer (i.e. DMAB PVA) on the particle size and encapsulation efficiency

-Faster EA in vitro release in the case of PVA-stabilized particles -Remarkably higher EA intestinal uptake in the case of DMABstabilized nanoparticles -Improved antioxidant properties compared to the suspension formulation
-In vivo tests in rats $-75,73$ and $87 \%$

-Yeast cell culof intestinal perture and a cell free meation in rats, system using PVA, PVA-

CS blend and DMAB as stabilizer, respectively -Good free radical scavenging effect

In vivo tests in rats

-Improved EA ora bioavailability -Ability to prevent cyclosporine Ainduced nephrotoxicity at 3-fold lower dose compared to free EA suspension -Antioxidant properties

In vivo tests in rats

-Improved efficacy of EA and coenzyme Q10 in high fat diet induced hyperlipidaemia -More effective at 3 -fold lower dose in reducing cholesterol, glucose and triglycerides levels and in improving endothelial function than the free compounds

-High loading efficiencies -Diffusion-based release and HCT-116) cell lines (Caco-2 -Cancer cells uptake [87] -Reduction of cell viability -Enhancement of oral bioavailability in vivo $140 \pm 2 \mathrm{~nm}$ and $230 \pm 3$

-Entrapment efficiencies of total drug (paclitaxel and EA), paclitaxel, and EA of $80 \%, 62.3 \%$, and $37.7 \%$, respectively -Controlled in vitro release of the two drugs over a longer period of time at a higher temperature
-Very high cellular

MCF-7 breast cancer cell line uptake -Higher cytotoxicity than free EA core shell nano-

particles 
Table 1. (Continued)

\begin{tabular}{|c|c|c|c|c|c|c|}
\hline & EA delivery system & Production process & $\begin{array}{l}\text { Physico-chemical } \\
\text { properties }\end{array}$ & Experimental model & Biological effect & Ref. \\
\hline \multirow[t]{2}{*}{ Blend systems } & $\begin{array}{l}\text { PLGA-PEG } \\
\text { nanoparticles }\end{array}$ & $\begin{array}{l}\text { Double emulsion- } \\
\text { solvent evaporation } \\
\text { method }\end{array}$ & - & $\begin{array}{l}\text { Human breast } \\
\text { cancer cell line } \\
\text { (MCF-7) }\end{array}$ & $\begin{array}{l}\text {-Nanoparticles } \\
\text { intracellular uptake } \\
\text {-Cancer cell growth } \\
\text { inhibition }\end{array}$ & [108] \\
\hline & $\begin{array}{l}\text { CS functionalised } \\
\text { PLGA and CS- PEG } \\
\text { decorated PLGA } \\
\text { nanoparticles }\end{array}$ & $\begin{array}{l}\text { Oil-in-water }(\mathrm{o} / \mathrm{w}) \\
\text { single emulsion } \\
\text { solvent evaporation } \\
\text { method }\end{array}$ & $\begin{array}{l}\text {-PLGA-CS-PEG as } \\
\text { optimal nanoprototype } \\
\text {-Average diameter in } \\
\text { the range } 150-300 \mathrm{~nm}\end{array}$ & $\begin{array}{l}\text { Human hepatocel- } \\
\text { lular carcinoma } \\
\text { (HepG2) and } \\
\text { colorectal cancer } \\
\text { (HCT-116) cell lines }\end{array}$ & $\begin{array}{l}\text { Potentiation of } \\
\text { apoptosis-mediated } \\
\text { cancer cell death }\end{array}$ & {$[88]$} \\
\hline
\end{tabular}

to obtain more stable, monodispersed particles with lower dimensions (average diameter of $148.5 \mathrm{~nm}$ ) and higher zeta potential values as compared to the use of PVA (average diameter $269.7 \mathrm{~nm}$ ) and PVA-CS (average diameter $359.6 \mathrm{~nm}$ in the case of PVA-CS 80:20). Concerning EA release from nanoparticles in $\mathrm{pH} 7.4$ phosphate buffer, it was rapid at the beginning and presented a successive slower sustained profile, with the following order: PVA $>$ PVA-CS $>$ DMAB. The slowest release rate from the PLGA-DMAB particles was ascribed to higher DMAB hydrophobicity with respect to PVA, whereas in the case of PVA-CS, it was due to the CS insolubility at alkaline $\mathrm{pH}$. The analysis of the in situ intestinal permeability of free EA and EA encapsulated within PLGA nanoparticles in rats revealed a $66,75,73$ and $87 \%$ permeation rate in the case of free EA or encapsulated EA using PVA, PVA-CS and DMAB, respectively [93].

Encapsulation of EA was also performed within PLGA and polycaprolactone (PCL) nanoparticles, following a comparable procedure (emulsion-diffusion-evaporation method, using DMAB and PVA as stabilizers, and PEG400 as cosolvent for EA solubilization) [86]. The type of used stabilizer strongly affected the particle size and encapsulation efficiency: particles with $\sim 120$ or $\sim 290 \mathrm{~nm}$ average diameter and $\sim 50 \%$ or $\sim 60 \%$ encapsulation index were obtained with DMAB and PVA, respectively. The same particles were able to sustain EA release in phosphate buffer in vitro over a period of 20 days and the release was faster from PVA-stabilized particles. In situ permeation studies in a rat model showed a remarkably higher EA intestinal absorption in the case of DMAB-stabilized nanoparticles, compared to PVA-stabilized particles. Finally, the designed nanoparticles prevented cyclosporine A-induced nephrotoxicity in rats at a three-fold lower dose than free EA suspension, due to the improved EA oral bioavailability and maintained antioxidant properties.

The co-encapsulation of two antioxidants, i.e. EA and coenzyme Q10 (10\% w/w with respect to polymer) within PLGA nanoparticles (average diameter size of $260 \mathrm{~nm}$ ) was also proposed [87]. In particular, the possible synergism between EA and coenzyme Q10 was investigated, in terms of beneficial effects on hyperlipidemia in high-fat diet fed rats. After 2 weeks of treatment, the nanoparticulate strategy seemed more promising and better performing than the oral suspension formulation of the same combination. In fact, the nanoparticles were equally or more effective at a three-fold lower dose in decreasing cholesterol, glucose and triglycerides levels and in stimulating endothelial functions.

Another polyester widely employed for the production of drug delivery particles, mentioned above in combination with PLGA, is PCL. EA-loaded PCL nanoparticles (average diameter size of $193 \mathrm{~nm}$ ), with high entrapment and loading efficiencies, were produced by means of the emulsiondiffusion-evaporation technique [109]. In vitro cellular uptake and nuclear localization of these nanoparticles was demonstrated through fluorometric imaging in Caco-2 and HCT-116 human colon cancer cells. Moreover, the EA-containing nanoparticles were more cytotoxic (6.9-fold) than the free EA molecule. Oral administration of EA-loaded nanoparticles to New Zealand white rabbits resulted in a significant increase of the absorption rate and AUC (3.6-fold), compared to free EA.

Even the combination of different polymers to encapsulate poorly soluble drugs has been extensively investigated $[88,98$, 110]. For instance, PLGA-PEG nanoparticles were proposed as carriers of pomegranate extract or individual polyphenols, such as punicalagin or EA, by using the double emulsionsolvent evaporation method. This method led to the production of spherical monodispersed nanoparticles with an average diameter of 150-200 nm [88]. The resulting EA-loaded nanoparticles were efficiently taken up by MCF-7 human breast cancer cells, with a maximum uptake at $24 \mathrm{~h}$, and showed enhanced anti-proliferative effects (from 2 to 12 -fold), compared to free EA.

In another study, CS and CS-PEG decorated PLGA nanoplatforms were investigated as carriers not only for EA, but also for two other bioactive compounds, i.e. quercetin and gallic acid, in order to protect them from phagocytosis and ensure their delivery to the target site [98]. The PLGACS-PEG nanoprototype (average diameter in the range 150$300 \mathrm{~nm}$ ) was identified as the optimal one. In fact, this delivery system remarkably decreased the $\mathrm{EA} \mathrm{IC}_{50}$ values in HepG2 human hepatocellular carcinoma cells. In particular, no change in $\mathrm{EA} \mathrm{IC}_{50}$ value was detected when delivered through PLGA nanoparticles, while a 1.5- and 2.7-fold decrease was observed for EA-encapsulated PLGA-CS and PLGA-CS-PEG nanoparticles, respectively, thus evidencing that the functionalization with CS and PEG improved EA cell penetration. 
Other authors developed dual-loaded core shell nanoparticles (particle size between $140 \pm 2 \mathrm{~nm}$ and $230 \pm 3 \mathrm{~nm}$ ), based on the temperature-sensitive amphiphilic copolymer poly $(N$-isopropylacrylamide) (NIPAAm))-PEG acrylate, loaded with the chemotherapeutic agent paclitaxel and EA by membrane dialysis method [108]. The entrapment efficiencies of the drug combination, paclitaxel, and EA were of $80 \%$, $62.3 \%$, and $37.7 \%$, respectively. Furthermore, nanoparticles showed a controlled and improved in vitro drug release over a longer period of time at a higher temperature. This co-delivery system also displayed very high cellular uptake that resulted in increased cytotoxicity against MCF-7 cells, in comparison to paclitaxel used as single agent; furthermore, it is likely that such nanoparticles might also represent a suitable strategy to overcome efflux-mediated drug resistance.

2.2.2. Complexes with cyclodextrins Many authors have used cyclodextrins, a family of cyclic oligosaccharides, in order to obtain complexes with EA (table 2). For example, methylated cyclodextrin inclusion complex allowed the enhancement of EA levels more than twice in the lung tissue, supporting the possibility of increasing its bioavailability by microencapsulating substances [111]. The use of methyl$\beta$-cyclodextrin $(\mathrm{Me}-\beta-\mathrm{CD})$ as a carrier increased EA levels in plasma (7-fold) and pancreas (5.8-fold) of the treated rats, compared to the treatment with free EA, suggesting improved bioavailability and tissue distribution [112].

Another study evaluated the influence of $\beta$-cyclodextrin $(\beta-C D)$ microspheres loaded with EA on the growth of HepG2 cells, demonstrating a dose- and time-dependent inhibition of cell proliferation, due to DNA damage and apoptosis [82]. Consistently, EA-loaded $\beta-\mathrm{CD}$ microspheres enhanced the antioxidant activity of EA and preserved its antimicrobial effects [115].

The EA-hydroxypropyl- $\beta$-CD inclusion complex, obtained with the mechanism of inclusion complexation through the freeze-drying method, also appeared to be a promising strategy to increase the anti-inflammatory/antioxidant activity of EA. This complex exerted a significant antioxidant activity on carrageenan-induced rat paw oedema [114] and anti-arthritis activity in a rat model, with reduction of hyperalgesia, oxidative stress and pro-inflammatory cytokines levels [113]. Remarkably enhanced EA solubility and in vitro dissolution by complexation with $\beta-C D$ with respect to free EA were also evidenced [95]. Moreover, the complexation with $\beta-C D$ positively influenced EA in vitro anti-inflammatory effects by protecting cells from protein denaturation and membrane lysis [95, 114].

EA-loaded $\beta$-CD NPs were proposed as an alternative antiprotozoal agent [116]. Indeed, the authors demonstrated the growth-inhibitory action in vitro against four Babesia species and Theileria parasites, and the chemotherapeutic efficacy in vivo in mice against $B$. microti. The cytotoxicity was evaluated in in vitro tests with Madin-Darby bovine kidney (MDBK), mouse embryonic fibroblast (NIH/3T3) and human foreskin fibroblast (HFF) cell lines, evidencing that EA loaded $\beta$-CD NPs were able to influence the cell viability with a halfmaximal effective concentration $\left(\mathrm{EC}_{50}\right)$ higher than $800 \mu \mathrm{M}$.
Recently, a pomegranate EA-hydroxypropyl- $\beta-C D$ inclusion complex was prepared by the stirring-ultrasonic method. This complex was able to inhibit $S$. aureus (Gram-positive bacterium) and E. coli (Gram-negative bacterium) growth, with an EA dose-dependent profile [117].

Thus, considering all the collected data, it is possible to conclude that cyclodextrins could be suitable delivery systems to improve EA bioavailability.

\subsubsection{Encapsulation within liposomes and niosomes Lipo-} somes consist of spherical bilayer vesicles formed by dispersion of polar lipids in aqueous solvents. Recently they have been largely utilized in biomedical, food and agricultural industries as carrier systems for both water and oil-soluble molecules, such as antimicrobials, flavours, antioxidants and bioactive agents [118]. The use of phospholipids from natural sources is gaining a lot of attention, since it allows a remarkable reduction in production costs with respect to synthetic phospholipids, thus favouring large-scale industrial applications. Reports about the use of liposomes for EA encapsulation are summarized in table 3 .

Unfortunately, liposomal systems tend to leak and lose the encapsulated components over time [121] and undergo gradual coalescence, particularly in low $\mathrm{pH}$ environments, which reduce surface charges [122]. Thus, in an attempt to overcome these drawbacks, soybean lecithin liposomes were coated with alternating layers of positively charged CS and negatively charged dextran, by means of layer-by-layer electrostatic deposition [19]. The obtained spherical monodispersed nanoparticles with four bilayers of biopolymers presented an apparent hydrodynamic diameter of $386.5 \pm 25.9 \mathrm{~nm}$ and surface charge of $-30.66 \pm 1.55 \mathrm{mV}$. This system showed better thermal and $\mathrm{pH}$ stability, as well as better release properties, good encapsulation efficiency and sustained release of EA [19]. Moreover, thermosensitive liposomal particles have been produced, for the co-delivery of nab-paclitaxel (paclitaxel bound to human serum albumin) and human serum albumin-EA complexes, improving drug blood retention and tumour growth inhibition in vivo. Indeed, after achieving the locally heated tumours, these systems rapidly release the complexes, facilitating their accumulation and matrix penetration [94].

Lately, niosomes have been considered as an efficient alternative to the liposomal drug carriers for the encapsulation of several biomolecules [123], including EA (table 3). They consist of vesicular colloidal drug carriers obtained by the selfassembly of non-ionic surfactants into vesicles, resembling the liposomes architecture [124]. This kind of carrier has been mainly exploited as dermal and transdermal drug delivery system [125-128]. EA-loaded niosomal formulations, obtained by using the reverse phase evaporation method, with Span 60 , Tween 60, their mixtures and cholesterol as surfactants/vesicle forming agents, solulan C24 as steric stabilizer, and PEG400, propylene glycol or methanol as solubilizer, were designed for dermal delivery. The obtained spherical multilamellar vesicles showed a good percentage of entrapment efficiency [96, 120] and were stable after four months of storage at $4{ }^{\circ} \mathrm{C}$ 
Table 2. Cyclodextrin complexes: physicochemical properties and biological effects.

\begin{tabular}{|c|c|c|c|c|}
\hline Complex & $\begin{array}{l}\text { Physico-chemical } \\
\text { properties }\end{array}$ & Experimental model & Biological effect & Ref. \\
\hline $\begin{array}{l}\text { Methylated cyclo- } \\
\text { dextrin inclusion } \\
\text { complex }\end{array}$ & - & In vivo tests in mice & $\begin{array}{l}\text { Two-fold increment of EA level in the } \\
\text { lung tissue }\end{array}$ & [111] \\
\hline $\begin{array}{l}\text { Methyl-beta- } \\
\text { cyclodextrin (Me- } \\
\beta-\mathrm{CD}) \text { complex }\end{array}$ & - & In vivo tests in rats & $\begin{array}{l}\text {-Increment of EA level up to } 5.8 \text {-fold } \\
\text { in the pancreas } \\
\text {-Increment of EA plasma levels up to } \\
\text { 7-fold } \\
\text {-Higher EA content in the duodenum }\end{array}$ & [113] \\
\hline $\begin{array}{l}\text { Hydroxypropyl- } \beta- \\
\text { CD complex }\end{array}$ & - & In vivo tests in rats & $\begin{array}{l}\text { Anti-arthritis activity by attenuation } \\
\text { of hyperalgesia, oxidative stress and } \\
\text { pro-inflammatory cytokines }\end{array}$ & [112] \\
\hline $\begin{array}{l}\text { Hydroxypropyl- } \beta \text { - } \\
\text { CDcomplex }\end{array}$ & - & In vivo tests in rats & $\begin{array}{l}\text { Enhanced anti-inflammatory and anti- } \\
\text { oxidant activity }\end{array}$ & [114] \\
\hline$\beta-\mathrm{CD}$ complex & $\begin{array}{l}\text { Remarkably } \\
\text { enhanced solubility } \\
\text { and in vitro dissolu- } \\
\text { tion of EA }\end{array}$ & $\begin{array}{l}\text { Fresh whole human } \\
\text { blood }\end{array}$ & $\begin{array}{l}\text { Protection of erythrocytes from mem- } \\
\text { brane lysis }\end{array}$ & [95] \\
\hline$\beta-\mathrm{CD}$ microspheres & - & $\begin{array}{l}\text { Human liver cancer } \\
\text { cell line (HepG2) }\end{array}$ & $\begin{array}{l}\text { Inhibition of tumour cells prolif- } \\
\text { eration, DNA damage and p53 up- } \\
\text { regulation }\end{array}$ & {$[82]$} \\
\hline $\begin{array}{l}\beta-\mathrm{CD} \text { and }(2- \\
\text { hydroxypropyl)- } \beta- \\
\text { CD complexes }\end{array}$ & $\begin{array}{l}\text {-Rapid release of } \\
\text { EA in the aqueous } \\
\text { medium at } 25^{\circ} \mathrm{C} \\
\text {-Enhanced EA water } \\
\text { solubility } \\
\text {-Higher EA stability } \\
\text {-Enhanced antioxid- } \\
\text { ant activity }\end{array}$ & $\begin{array}{l}\text { Fungi, gram-negative } \\
\text { and gram-positive } \\
\text { bacteria }\end{array}$ & $\begin{array}{l}\text { Preservation of the antimicrobial } \\
\text { activity }\end{array}$ & [115] \\
\hline$\beta-C D$ nanoparticles & - & $\begin{array}{l}\text { Madin-Darby bovine } \\
\text { kidney (MDBK), } \\
\text { mouse embryonic } \\
\text { fibroblast (NIH/3T3) } \\
\text { and human foreskin } \\
\text { fibroblast (HFF) cell } \\
\text { lines }\end{array}$ & $\begin{array}{l}\text {-Growth-inhibitory action in vitro } \\
\text { against four Babesia species and Thei- } \\
\text { leria parasites } \\
\text {-Chemotherapeutic efficacy in vivo } \\
\text { against } B \text {. microti -Cytotoxicity with a } \\
\text { half-maximal effective concentration } \\
\left(\mathrm{EC}_{50}\right) \text { higher than } 800 \mu \mathrm{M}\end{array}$ & [116] \\
\hline $\begin{array}{l}\text { Hydroxypropyl- } \\
\beta-C D \text { inclusion } \\
\text { complex }\end{array}$ & - & S. aureus and E. coli & $\begin{array}{l}\text { Ability to inhibit bacteria growth, with } \\
\text { an EA dose-dependent profile }\end{array}$ & [117] \\
\hline
\end{tabular}

[96]. Furthermore, in an in vitro skin permeation and distribution test, the niosomes delivered higher EA amounts into the deeper layer of the skin, as compared to free EA [120]. DMSO or NMP, tested as skin penetration enhancers, improved the EA entrapment efficiency and the EA permeation through the human skin from the EA-loaded niosomes [96]. In particular, DMSO made it possible to achieve the highest EA amount in the epidermis (penetration depth between 30-90 $\mu \mathrm{m}$ ); conversely, NMP led to the highest EA amount in the acceptor medium resembling the skin condition, i.e. a mixture of isotonic phosphate buffer $\mathrm{pH} 5.5$ and isopropyl alcohol (ratio 90:10, \% v/v), and could be used for EA dermal delivery (penetration depth of 90-120 $\mu \mathrm{m}$ ).

Recently, nanoliposomes have been tested as EA carriers to prevent its degradation and improve its antioxidant properties [119]. EA encapsulated within nanoliposomes demonstrated a higher ability to prevent in vitro lipid peroxidation than free EA, and in vivo experiments evidenced that both free EA and encapsulated EA were able to avoid rat liver damage induced by the alkylating agent cyclophosphamide.

\subsection{Ellagic acid molecular dispersion in polymer matrices}

Molecular dispersion within polymer matrices (amorphous solid dispersion, ASD) is considered another appealing modality to increase drug oral bioavailability [129, 130]. Taking into account that low water solubility can be ascribed to high melting temperature and, thus, high crystallinity, it is expected that embedding EA in the metastable amorphous state within a polymer matrix would successfully improve its bioavailability. Effective ASD delivery systems should be able to stabilize the released drug against crystallization even under supersaturated concentrations, as it occurs in the gastrointestinal tract. Thus, the polymer to be used for ASD device must have proper water solubility at least in the $\mathrm{g} \mathrm{ml}^{-1}$ range. 
Table 3. Liposomal/niosomal systems: physicochemical properties and biological effects.

\begin{tabular}{|c|c|c|c|c|}
\hline $\begin{array}{l}\text { EA liposomal/niosomal } \\
\text { system }\end{array}$ & $\begin{array}{l}\text { Physicochemical } \\
\text { properties }\end{array}$ & Experimental model & Biological effect & Ref. \\
\hline $\begin{array}{l}\text { Soybean lecithin liposomes } \\
\text { coated with alternating } \\
\text { layers of positively charged } \\
\text { chitosan and negatively } \\
\text { charged dextran }\end{array}$ & $\begin{array}{l}\text {-Better thermal stability } \\
\text {-Better pH stability and } \\
\text { release properties }\end{array}$ & A cell free system & - & [19] \\
\hline $\begin{array}{l}\text { Thermosensitive liposomes } \\
\text { for co-delivery of human } \\
\text { serum albumin-paclitaxel } \\
\text { and human serum albumin- } \\
\text { EA complexes }\end{array}$ & & Murine pancreatic cancer & $\begin{array}{l}\text { Strong tumour growth } \\
\text { inhibition and apoptosis in } \\
\text { vivo, in combination with } \\
\text { heat }\end{array}$ & [94] \\
\hline Nanoliposomes & $\begin{array}{l}\text {-Improved stability } \\
\text {-Enhanced antioxidant } \\
\text { properties } \\
\text {-Higher ability to prevent } \\
\text { in vitro lipid peroxidation } \\
\text { than free EA }\end{array}$ & - & $\begin{array}{l}\text { Ability to prevent rat liver } \\
\text { damage induced by cyc- } \\
\text { lophosphamide for both } \\
\text { free EA and encapsulated } \\
\text { EA in in vivo experiments } \\
\text { and increased hepato- } \\
\text { protective action against } \\
\text { cyclophosphamide-induced } \\
\text { liver damage }\end{array}$ & [119] \\
\hline Niosomes & $\begin{array}{l}\text {-Spherical multilamellar } \\
\text { vesicles with polydis- } \\
\text { persity index (PI) values } \\
\text { lower than } 0.4 \\
\text {-High entrapment effi- } \\
\text { ciency } \\
\text {-Delivery of higher amount } \\
\text { of EA into the skin deeper } \\
\text { layer compared to free EA } \\
\text { solution } \\
\text {-Improvement of EA } \\
\text { entrapment efficiency, } \\
\text { depending on the used skin } \\
\text { penetration enhancers (i.e. } \\
\text { DMSO and NMP) }\end{array}$ & $\begin{array}{l}\text { Ex vivo human epidermis } \\
\text { and underlying dermis }\end{array}$ & $\begin{array}{l}\text { Improved skin permeation } \\
\text { and entrapment compared } \\
\text { to free EA }\end{array}$ & {$[96,120]$} \\
\hline
\end{tabular}

Drug solid dispersions within polymers are usually prepared starting from a solution by means of different technologies, such as freeze-drying, spray-drying, co-precipitation, rotary evaporation and film casting, or by co-extrusion. The commonly used polymeric matrices are hydrophilic polymers, including the hydrosoluble polyvinylpyrrolidinone (PVP), water-swellable and/or dispersible polymers like cellulose acetate phthalate [131], hydroxypropylmethylcellulose acetate succinate (HPMCAS) [132], and carboxymethylcellulose acetate butyrate (CMCAB) [133, 134]. Also cellulosecarboxyalkanoates have been proposed as crystallization inhibitors [135, 136] and ASD polymers [137, 138], due to their acceptable toxicity profile, high glass transition temperatures, and the ability of the pendent carboxyl group to trigger $\mathrm{pH}$-influenced drug release and generate strong hydrogen bonding with the drug.

Different carboxyl-containing cellulose derivatives [i.e. the relatively hydrophobic $\mathrm{CMCAB}$, the highly hydrophobic cellulose acetate adipate propionate (CAAdP), and the hydrophilic HPMCAS] were tested for their ability to form
ASDs with EA (up to 25 wt. \%) [59]. The EA dissolution from ASDs was then compared to that obtained from pure crystalline EA and EA/PVP solid dispersions [59], taking into account that these polymers present different abilities to solubilize EA from ASDs (e.g. at pH 6.8 PVP » HPMCAS » $\mathrm{CMCAB}$ ). The investigated ASDs demonstrated a remarkably better stability towards crystallization and EA concentrations in comparison with pure crystalline EA. The cellulose derivative ASDs also showed extremely slow $(<4 \%)$ EA release at $\mathrm{pH} 1.2$ and faster, though incomplete, drug release at $\mathrm{pH} 6.8$ (up to $35 \%$ for HPMCAS solid dispersions). Among the different carboxyl-containing cellulose derivatives, HPMCAS most effectively stabilized EA towards chemical degradation and recrystallization in solution. Indeed, the release from ASDs in pure CAAdP or CMCAB was extremely slow and did not guarantee sufficient EA dissolution, whereas release from the more hydrosoluble polymers (PVP and HPMCAS) made it possible to achieve very high EA concentrations. However, EA was dissolved from ASD in PVP rapidly and almost completely (up to $92 \%$ ) at $\mathrm{pH} 6.8$, but was also released at $\mathrm{pH} 1.2$, with 
consequent fast recrystallization. Thus, HPMCAS was identified as the most promising matrix for EA amorphous solid dispersion, stabilization, solubilization, and bioavailability improvement.

Alfei et al [97] prepared other three different ASD based formulations: (i) EA solid microdispersion, characterised by $22 \% \mathrm{w} / \mathrm{w}$ drug loading, and a 30-fold improved water solubility, as well a marked radical scavenging activity, using water and low methoxylated pectin as food compatible excipient, by means of spray drying technology; (ii) EA nanodispersions (60-70 nm) using a strongly hydrophilic dendriplex, containing non-polyamidoamine; (iii) an amphiphilic dendriplex with 46 and 53\% w/w drug loading and good antioxidant power. The EA solubility improvement was remarkably greater than that observed before, with an increment of 3001000 -fold in water and of 75-fold in ethanol, suggesting consequent enhanced bioavailability, and good antioxidant power.

\subsection{Other strategies for EA delivery}

In addition to the previously described approaches (i.e. encapsulation, complexation and dispersion), further strategies have been proposed in order to enhance the EA bioavailability and therapeutic action. For example, Montes et al [139] produced EA microparticles by a supercritical antisolvent process, followed by a successive co-precipitation with eudragit as a coating agent. These EA microparticles dissolved more rapidly than raw EA, faster in simulated gastric juice than in simulated intestinal fluid. The co-precipitates of EA and eudragit resulted in spherical microparticles of eudragit, surrounding sticks and flowers of EA, characterized by a quicker release of EA with respect to only EA made microparticles.

Micronization of EA was found to increase its solubility, by means of anti-solvent precipitation process, with NMP as solvent and deionized water as anti-solvent; a following lyophilization process was carried out in order to obtain a freeze-dried powder. The resulting submicrometric EA powder (m-EA; mean particle size of $429.2 \pm 7.6 \mathrm{~nm}$ ) was characterized by the same chemical structure of raw EA, but with greatly reduced crystallinity and higher 2,2-diphenyl1-picrylhydrazyl radical scavenging activity. Moreover, mEA presented dissolution rate, solubility and bioavailability approximately 2-, 6.5- and 2-fold higher, respectively, compared with orally administered EA, and its physical stability was demonstrated through $\mathrm{x}$-ray diffraction measurements [140]. Thus, the anti-solvent precipitation method was recognized as a promising strategy, since it is rapid, needs low equipment requirements, and can be easily scaled up, with respect to the processes commonly used for EA encapsulation, such as emulsion-diffusion-evaporation [83, 85, 86], spray drying [59], co-precipitation [59], rotary evaporation [59] and ionic gelation [84] methods.

EA NPs, produced by means of antisolvent precipitation using a syringe pump (APSP) method, were also demonstrated to be able to enhance EA solubility and bioavailability. Needle-shaped or rod-like crystal structures with a good dispersion [116] were obtained and showed growth inhibition only on HFF cells, with an $\mathrm{EC}_{50}$ value of $790 \pm 5.4 \mu \mathrm{M}$, but not on the other tested models, i.e. MDBK and NIH/3T3 cell lines.

Some authors proposed the use of gel carriers for EA delivery (table 4). A CS/ $\beta$-glycerophosphate thermo-sensitive gel was produced to encapsulate EA and its antitumour effects on brain cancer cells (human U87 glioblastoma and rat C6 glioma cell lines) was investigated. Results suggested that gels containing $1 \%$ EA (w/v) significantly reduced glioma cell viability and increased the EA release rate by 2.5 -fold [110]. Biodegradable disulfide crosslinked PEG-based nanogel (poly(oligo(ethylene oxide) methyl ether methacrylate)) [P(OEOMA)], synthesized via AGET (activator generated electron transfer) and ATRP (atom transfer radical polymerization), was employed to encapsulate EA (10-20 wt. \%) [92]. The average size increased from $144.6 \pm 39.5 \mathrm{~nm}$ for neat nanogels to $217.8 \pm 105.5$ and $633 \pm 160.1 \mathrm{~nm}$ with the EA amount, at the lowest and highest drug loading level, respectively. The encapsulation efficiency was about $25 \%$ and $23.5 \%$ for EA stoichiometric amounts of 10 and $20 \mathrm{wt} \%$, respectively, and the radical scavenging activity of the nanogels was demonstrated using the HeLa human cervical cancer cell line.

Also EA-phospholipid complexes based on the selfnanoemulsifying drug delivery system (SNEDDS), by an antisolvent, with a mean globule size of $106 \pm 0.2 \mathrm{~nm}$ and cloud point at $83-85^{\circ} \mathrm{C}$, showed improved EA lipophilicity, higher oral bioavailability, in vitro drug release, and permeation in $e x$ vivo studies, with respect to EA suspension [141].

Similarly, an innovative food-grade EA based selfnanoemulsifying system (EA-SNEDS), based on $45 \mathrm{wt} \%$ PEG, 45 wt. $\%$ polysorbate, 10 wt.\% caprylic/capric triacylglycerol, was developed [142] and characterized by a mean droplet size of around $120 \mathrm{~nm}$, for potential applications in dietary supplements and functional foods. Pharmacokinetic studies in the rat model indicated that the EA oral bioavailability was enhanced 6.6- and 3.2-fold with respect to aqueous suspensions and pomegranate extract, respectively.

Another strategy to improve the EA solubility is represented by the development of supersaturatable selfmicroemulsifying drug delivery system (S-SMEDDS). Zheng et al [143] proposed a $10 \%$ ethyl oleate, $67.5 \%$ Tween 80, 22.5\% PEG400, 0.5\% PVP K30 and $4 \mathrm{mg} \mathrm{g}^{-1}$ EA SSMEDDS, obtaining spherical particles with a droplet size of about $40 \mathrm{~nm}$. Faster dissolution and quicker EA release from S-SMEDDS than from SMEDDS were revealed in in vitro dissolution studies. Furthermore, the EA-loaded S-SMEDDS showed remarkably higher in vitro and in vivo antioxidant abilities than free EA at the same concentrations. This interesting experimental evidence was ascribed to the use of a small amount of PVP K30 as precipitation inhibitor, since it was able to efficiently avoid EA nucleation.

Very recently, micellar nanodelivery tools, based on D- $\alpha$ tocopheryl polyethylene glycol succinate (TPGS), were formulated for EA distribution by using a film-hydration method 
Table 4. Other strategies for EA delivery.

\begin{tabular}{|c|c|c|c|c|c|}
\hline EA delivery system & Production process & $\begin{array}{l}\text { Physico-chemical proper- } \\
\text { ties }\end{array}$ & Experimental model & Biological effect & Ref. \\
\hline $\begin{array}{l}\mathrm{CS} / \beta \text {-glycerophosphate } \\
\text { (thermo-sensitive gel) }\end{array}$ & Dialysis & $\begin{array}{l}\text { Increment of EA release } \\
\text { rate by } 2.5 \text {-fold in the } \\
\text { presence of lysozyme }\end{array}$ & $\begin{array}{l}\text { Brain cancer cells } \\
\text { (U87 human glioblastoma } \\
\text { cell line and C6 rat } \\
\text { glioma cells) }\end{array}$ & $\begin{array}{l}\text { Inhibition of } \\
\text { cancer cell growth in a } \\
\text { concentration-dependent } \\
\text { manner }\end{array}$ & [110] \\
\hline $\begin{array}{l}\text { Biodegradable disulfide } \\
\text { crosslinked PEG-based } \\
\text { nanogels }\end{array}$ & $\begin{array}{l}\text { AGET (activator gener- } \\
\text { ated electron transfer) } \\
\text { and ATRP (atom transfer } \\
\text { radical polymerization) }\end{array}$ & $\begin{array}{l}\text {-Increase in nanogels size } \\
\text { with the EA amount } \\
\text {-Quite good encapsula- } \\
\text { tion efficiency (23-25\%) }\end{array}$ & $\begin{array}{l}\text { Human cervical cancer } \\
\text { cell line (Hela) }\end{array}$ & $\begin{array}{l}\text {-No cytotoxicity } \\
\text {-Radical scavenging } \\
\text { ability }\end{array}$ & [92] \\
\hline $\begin{array}{l}\text { Nano-sized metalla } \\
\text { prisms }\end{array}$ & Self-assembly & - & $\begin{array}{l}\text { Human hepatocellu- } \\
\text { lar (SK-hep-1), gastric } \\
\text { (AGS) and lung (A549) } \\
\text { carcinoma cell lines }\end{array}$ & $\begin{array}{l}\text { Macrophage-dependent } \\
\text { anticancer activity } \\
\text { through modulation } \\
\text { of cytokine expression } \\
\text { (G-CSF and Rantes) }\end{array}$ & [90] \\
\hline $\begin{array}{l}\text { Submicrometric EA } \\
\text { powder }\end{array}$ & $\begin{array}{l}\text { Anti-solvent precipita- } \\
\text { tion process, followed by } \\
\text { lyophilization }\end{array}$ & $\begin{array}{l}\text {-EA powder physical } \\
\text { stability } \\
\text {-Greatly reduced crys- } \\
\text { tallinity with respect to } \\
\text { raw EA }\end{array}$ & $\begin{array}{l}\text { In vivo EA plasma con- } \\
\text { centration in rats }\end{array}$ & $\begin{array}{l}\text {-Dissolution rate, sol- } \\
\text { ubility and bioavailab- } \\
\text { ility approximately 2-, } \\
6.5 \text { - and } 2 \text {-fold higher, } \\
\text { respectively, compared to } \\
\text { free EA }\end{array}$ & [140] \\
\hline $\begin{array}{l}\text { EA-phospholipid com- } \\
\text { plexes }\end{array}$ & Anti-solvent method & $\begin{array}{l}\text {-Improved EA lipophili- } \\
\text { city } \\
\text {-Higher in vitro EA } \\
\text { release }\end{array}$ & $\begin{array}{l}\text { Ex vivo tests on rat stom- } \\
\text { ach and small intestine }\end{array}$ & $\begin{array}{l}\text {-Higher EA oral bioavail- } \\
\text { ability and increased } \\
\text { permeation }\end{array}$ & [141] \\
\hline EA microparticles & $\begin{array}{l}\text { Supercritical antisolvent } \\
\text { process, with a sub- } \\
\text { sequent coprecipitation, }\end{array}$ & $\begin{array}{l}\text {-Faster EA dissolution } \\
\text { from EA microparticles } \\
\text { than raw EA and in simu- } \\
\text { lated gastric fluid than in } \\
\text { simulated intestinal fluid } \\
\text {-Quicker release of EA } \\
\text { from the co-precipitates } \\
\text { of EA and eudragit with } \\
\text { respect to EA micro- } \\
\text { particles }\end{array}$ & A cell free system & - & [139] \\
\hline EA nanoparticles & $\begin{array}{l}\text { Antisolvent precipitation } \\
\text { using a syringe pump } \\
\text { (APSP) method }\end{array}$ & $\begin{array}{l}\text {-Needle-shaped or rod- } \\
\text { like crystal structures } \\
\text {-Good dispersion }\end{array}$ & $\begin{array}{l}\text { Four Babesia species and } \\
\text { Theileria parasites } \\
\text { - } B \text {. microti in vivo chemo- } \\
\text { therapeutic efficacy in } \\
\text { mice } \\
\text {-Madin-Darby bovine } \\
\text { kidney (MDBK), mouse } \\
\text { embryonic fibroblasts } \\
\text { (NIH/3T3) and human } \\
\text { foreskin fibroblasts (HFF) }\end{array}$ & $\begin{array}{l}\text {-High antiprotozoal activ- } \\
\text { ity in vitro } \\
\text {-High chemotherapeutic } \\
\text { efficacy in vivo } \\
\text {-Growth inhibition on } \\
\text { HFF with an } \mathrm{EC}_{50} \text { value } \\
\text { of } 790 \pm 5.4 \mu \mathrm{M}\end{array}$ & [116] \\
\hline $\begin{array}{l}\text { EA/PEG/polysorbate/ } \\
\text { caprylic/capric } \\
\text { triacylglycerol } \\
\text { self-nanoemulsifying } \\
\text { system }\end{array}$ & Self-emulsion & $\begin{array}{l}\text {-Mean droplet size of } \\
\text { around } 120 \mathrm{~nm} \\
\text {-Enhanced EA oral } \\
\text { bioavailability (6.6- and } \\
\text { 3.2-fold with respect to } \\
\text { aqueous suspensions and } \\
\text { pomegranate extract, } \\
\text { respectively) }\end{array}$ & In vivo studies in rat & - & [142] \\
\hline $\begin{array}{l}\text { Self-nanoemulsifying } \\
\text { drug delivery system } \\
\text { (SNEDDS), based on the } \\
\text { phospholipid complex } \\
\text { technique }\end{array}$ & - & $\begin{array}{l}\text {-Enhanced lipophilicity } \\
\text {-Mean globule size: } \\
106 \pm 0.2 \mathrm{~nm} \\
\text {-Cloud point: } 83-85{ }^{\circ} \mathrm{C} \\
\text {-Increasing drug loading }\end{array}$ & $\begin{array}{l}\text { Ex vivo tests on rat stom- } \\
\text { ach and small intestine }\end{array}$ & $\begin{array}{l}\text { Increased permeability } \\
\text { compared to free EA }\end{array}$ & [141] \\
\hline
\end{tabular}


Table 4. (Continued)

\begin{tabular}{|c|c|c|c|c|c|}
\hline EA delivery system & Production process & $\begin{array}{l}\text { Physico-chemical } \\
\text { properties }\end{array}$ & Experimental model & Biological effect & Ref. \\
\hline $\begin{array}{l}\text { EA/ethyl oleate/Tween } \\
\text { 80/PEG400\%/PVP K30S- } \\
\text { SMEDDS }\end{array}$ & Self-emulsion & $\begin{array}{l}\text {-Higher in vitro drug } \\
\text { release and permeation } \\
\text { compared to EA suspen- } \\
\text { sion } \\
\text {-Enhanced EA release } \\
\text { and oral bioavailability } \\
\text {-Spherical particles with } \\
\text { a droplet size of about } \\
40 \text { nm } \\
\text {-Faster EA dissolution } \\
\text { and release } \\
\text {-Remarkably higher in } \\
\text { vitro and in vivo antioxid- } \\
\text { ant abilities than free EA } \\
\text { at the same concentration }\end{array}$ & - & - & [143] \\
\hline $\begin{array}{l}\text { Micellar nano-delivery } \\
\text { tool for EA, based on } \\
\text { D- } \alpha \text {-tocopheryl poly- } \\
\text { ethylene glycol succinate } \\
\text { (TPGS) }\end{array}$ & Film-hydration method & $\begin{array}{l}\text {-Spherical nano- } \\
\text { particles (diameter of } \\
113.2 \pm 23 \mathrm{~nm}, \text { PDI of } \\
0.260 \pm 0.038 \text { ) } \\
\text {-Drug-encapsulation effi- } \\
\text { ciency of } 88.67 \% \pm 3.21 \\
\text {-Sustained in vitro release } \\
\text { profile in phosphate- } \\
\text { buffer saline }\end{array}$ & $\begin{array}{l}\text { Human ovarian cancer } \\
\text { cells (OVACR } 3 \text { cell line) }\end{array}$ & $\begin{array}{l}\text {-Enhanced EA bioavail- } \\
\text { ability, and anticancer } \\
\text { activity } \\
\text {-Higher cytotoxicity than } \\
\text { free drug and TPGS, with } \\
\text { a dose dependent profile } \\
\text { (IC50 value of } 12.36 \mu \mathrm{M} \text { ) } \\
\text {-Ability to inhibit the } \\
\text { G1 phase of cell cycle, } \\
\text { inducing cancer cells } \\
\text { apoptosis }\end{array}$ & [144] \\
\hline $\begin{array}{l}\text { Lactoferrin-chondroitin } \\
\text { sulfate nanocomplex for } \\
\text { doxorubicin and EA tar- } \\
\text { geted co-delivery }\end{array}$ & - & $\begin{array}{l}\text {-Particles of } 192.3 \mathrm{~nm} \\
\text {-Faster release of EA, } \\
\text { followed by doxorubicin }\end{array}$ & $\begin{array}{l}\text { Human A549 lung cancer } \\
\text { cells }\end{array}$ & $\begin{array}{l}\text {-Higher cytotoxicity and } \\
\text { cell internalization medi- } \\
\text { ated via Tf and CD44 } \\
\text { receptors }\end{array}$ & [145] \\
\hline EA loaded SLNs & $\begin{array}{l}\text { Hot homogenization } \\
\text { technique }\end{array}$ & $\begin{array}{l}\text {-Particles with an average } \\
\text { size of } 96 \mathrm{~nm} \text { and an } \\
\text { encapsulation efficiency } \\
\text { of } 88 \% \\
\text {-A burst EA release in } \\
\text { the first hours, followed } \\
\text { by a sustained release } \\
\text { until } 72 \text { h in in vitro drug } \\
\text { release study }\end{array}$ & $\begin{array}{l}\text { Human prostate cancer } \\
\text { cell line (PC3) }\end{array}$ & $\begin{array}{l}\text { Ability to inhibit cells } \\
\text { growth in a lower } \mathrm{IC}_{50} \\
\text { value with respect to free } \\
\text { EA (i.e. } 61 \mu \mathrm{M} v s 82 \mu \mathrm{M} \\
\text { after } 48 \mathrm{~h} \text { and } 51 \mu \mathrm{M} v s \\
65 \mu \mathrm{M} \text { after } 72 \mathrm{~h} \text {, respect- } \\
\text { ively) }\end{array}$ & [146] \\
\hline $\begin{array}{l}\text { EA and vancomycin } \\
\text { loaded SLNs }\end{array}$ & $\begin{array}{l}\text { Solvent evaporation- } \\
\text { ultrasonication technique }\end{array}$ & $\begin{array}{l}\text {-Particles of } 164 \mathrm{~nm} \text {, } \\
\text { with a zeta potential of } \\
14.2 \mathrm{mV} \\
\text {-Vancomycin and EA } \\
\text { entrapment efficiency } \\
\text { of } 35.6 \% \text { and } 94.8 \% \text {, } \\
\text { respectively }\end{array}$ & $\begin{array}{l}\text { In vivo tests on a group } \\
\text { of animals treated with } \\
\text { vancomycin-EA SLNs } \\
\text { and a control group } \\
\text { (treated with free van- } \\
\text { comycin) }\end{array}$ & $\begin{array}{l}\text { Non-significant differ- } \\
\text { ences between levels of } \\
\text { all tested kidney functions } \\
\text { parameters (i.e. serum } \\
\text { creatinine, urea, glucose, } \\
\text { calcium, sodium, and } \\
\text { potassium) }\end{array}$ & [147] \\
\hline
\end{tabular}

[144]. Spherical nanoparticles (diameter of $113.2 \pm 23 \mathrm{~nm}$, polydispersion index (PDI) of $0.260 \pm 0.038$ ) with a drug-encapsulation efficiency of $88.67 \% \pm 3.21$ were obtained and a sustained in vitro release profile, with $67.8 \%$ cumulative release within $12 \mathrm{~h}$, was revealed in phosphatebuffer saline. The enhanced EA bioavailability and anticancer activity were demonstrated by the decreased fluorescence unit in ROS activity assay, and by in vitro tests with human ovarian cancer cells (OVACR3 cell line), evidencing higher cytotoxicity than that of free drug and TPGS, with a dosedependent profile $\left(\mathrm{IC}_{50}\right.$ value of $12.36 \mu \mathrm{M}$ ). It was postulated that the EA-loaded TPGS micelles were able to stop the G1 phase of the cell cycle, probably through the suppression of p15 and p21 genes expression and the induction of apoptosis.

Doxorubicin and EA loaded lactoferrin-chondroitin sulfate nanocomplexes were produced for the targeted drug codelivery to lung cancer [145]. The obtained particles of 


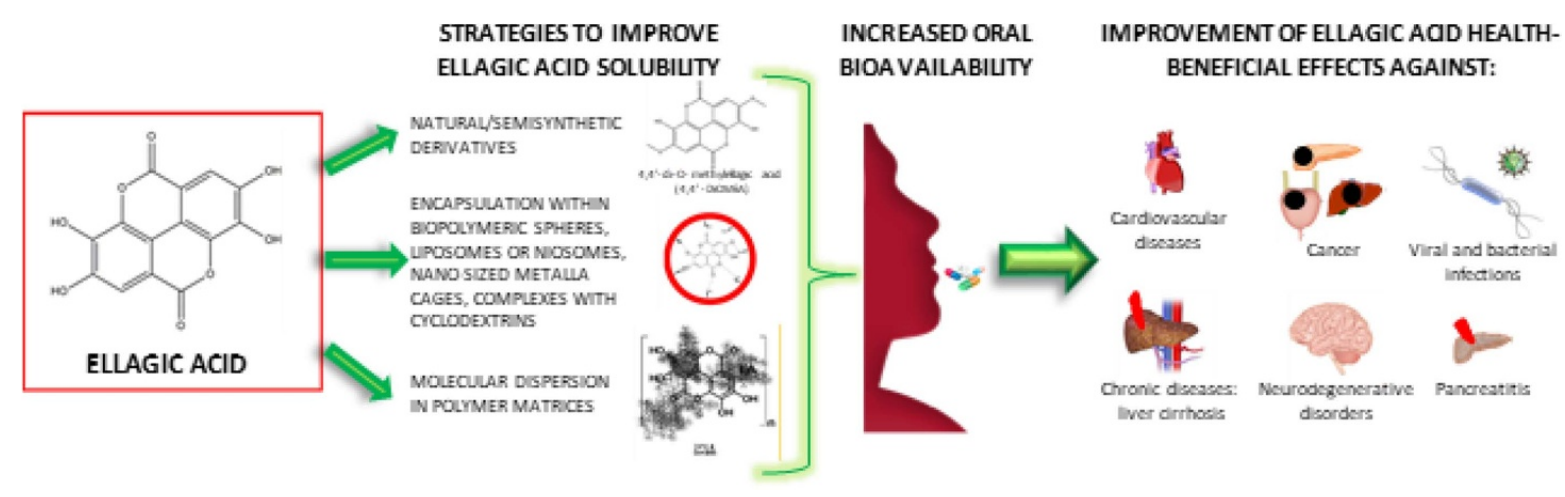

Figure 5. Proposed strategies to improve EA solubility, and, thus, its bioavailability and expected improvement of its health benefits.

$192.3 \mathrm{~nm}$ showed a faster release of EA and higher cytotoxicity and internalization into A549 lung cancer cells, mediated via transferrin (Tf) and CD44 receptors.

Recently, solid lipid nanoparticles (SLNs) have been proposed as EA delivery systems [146, 147]. SLNs with an average size of $96 \mathrm{~nm}$ and an encapsulation efficiency of $88 \%$, obtained by hot homogenization technique, improved EA bioavailability and anticancer activity against the PC3 human prostate cancer cell line [146]. In detail, a burst EA release in the first hours, followed by a sustained release until $72 \mathrm{~h}$, was recorded by an in vitro drug release assay. Moreover, cytotoxicity tests demonstrated that EA-loaded SLNs were able to inhibit the prostate cancer cells growth at a lower $\mathrm{IC}_{50}$ value with respect to free EA (i.e. $61 \mu \mathrm{M} v s 82 \mu \mathrm{M}$ for $48 \mathrm{~h}$ and $51 \mu \mathrm{M} v s 65 \mu \mathrm{M}$ for $72 \mathrm{~h}$, respectively). SLNs, produced by means of a solvent evaporation-ultrasonication technique, were employed for the co-delivery of EA and vancomycin loaded SLNs, in order to reduce/avoid nephrotoxicity of vancomycin, thanks to EA kidney protective action [147]. The obtained particles were characterized by particle size of $164 \mathrm{~nm}$, zeta potential of $14.2 \mathrm{mV}$ and vancomycin and EA entrapment efficiency of $35.6 \%$ and $94.8 \%$, respectively. Through in vivo tests carried out on a group of animals treated with vancomycin-EA SLNs and a control group (treated with free vancomycin), non-significant differences between levels of all tested kidney function parameters (i.e. serum creatinine, urea, glucose, calcium, sodium, and potassium) were revealed. On the other hand, the group treated with free vancomycin presented remarkable differences in all tested parameters.

Finally, a non-polymeric system, based on the use of nanosized metalla-cages, was also proposed [90]. Unlike free EA, EA encapsulated in metalla-prisms was able to induce cytotoxic effects in A549 human lung cancer cells and to modulate the expression levels of proteins involved in the immune response.

\section{Concluding remarks and future perspectives}

EA is a polyphenolic flavonoid present in different edible fruits and seeds, which exerts interesting pharmacological effects, such as protection against inflammation, diabetes, cardiovascular and liver diseases and cancer, as well as neurodegenerative disorders (figure 2).
EA occurs in nature as a free molecule or as complex polymers called ETs. After ingestion of polyphenols containing foods and beverages, a small amount of free EA is directly absorbed in the stomach. ETs, which are resistant to gastric metabolism, are hydrolysed in the small intestine. This intestinal uptake occurs by passive diffusion, based on a concentration gradient not involving specific transporters. Absorbed EA is then converted to inactive metabolites, which are eliminated through the urine $1-5 \mathrm{~h}$ after ingestion, while the unabsorbed EA is metabolized by the gut microbiota in the colon, giving a family of EA natural derivatives known as urolithins.

In general, low absorption and rapid elimination, i.e. poor bioavailability after oral administration, characterize EA pharmacokinetics. Moreover, the worldwide intake of EA in humans largely varies, but it is usually below the desirable levels to show clinical effects.

In such a context, several chemical derivatives or new EA delivery formulations have been proposed, including the encapsulation within nanocarriers and the molecular dispersion within polymer matrices, in order to improve the pharmacokinetic features and the therapeutic efficacy of EA (figure 5). Briefly, in recent years, several EA containing microor nanoparticulate systems have been developed, including microspheres, nanoparticles, $\mathrm{pH}$-dependent microassemblies, nano-sized metalla-cages, zinc layered hydroxide nanohybrid and nanogels. The possibility to increase EA bioavailability and efficacy through nanotechnology-based delivery systems was demonstrated by several studies, supporting the hypothesis that the improvement in EA solubility is a feasible approach to enhance its oral bioavailability and, consequently, its therapeutic efficacy. However, the same studies have also highlighted the requirement of further and deeper investigation to validate this approach [98]. The use of nanocarriers can be considered a relatively innovative, recent and in continuous evolution nanotechnological approach, particularly as promising tools for cancer treatment [148]. However, a lot of challenges must be faced, and several criticisms have to be addressed, such as the biodistribution, the biocompatibility, the improvement of the localization, and the in vivo efficacy. Indeed, the real clinical application and commercialization of drug nanocarriers require an accurate analysis of the safety profile [77]; more studies focused on the cytotoxic aspects and 
the comprehension of the underneath biological mechanisms are strictly required. The design of molecularly engineered biopolymers, as well as of smart materials, able to sense and selectively reply to specific physiological and biological signals, has been aimed at overcoming the remarkable limits of achieving efficient administration of therapeutics, promoting a controlled intracellular delivery of both hydrophobic drugs and macromolecular biotherapeutics, such as proteins and nucleic acids [76].

An attractive approach to be pursued in the future concerning the clinical applications of drug delivery systems loaded with EA is represented by the incorporation of tumourtargeting ligands on the particles surface [109]. Such a strategy should allow us to enhance the EA concentration at the tumour site after systemic administration, and, thus, to implement the EA clinical relevance. At the same time, the clinical application of such targeted systems could be prevented by the stability of nanomaterials, the development of multi-drug resistance, and the dysregulated accumulation of cancer cells [148]. For these reasons, new strategies have been and are actually being proposed, such as the obtainment of core-shell structures [108], and the coating/decoration of the nanoparticles shell with multiple chemically or physically active components to allow a targeted delivery of different drugs and combine their properties [94, 108, 145, 147].

Moreover, it would be very interesting to apply wireless technology to transdermally implantable drug delivery devices as a non-invasive strategy to allow the in situ release encapsulated drugs and molecules [149, 150], by using wirelessly controlled microchips, micropumps, microvalves, and magnetic robots [151].

\section{Acknowledgments}

The studies performed in the Graziani G. laboratory were supported in part by the Italian Association for Cancer Research (AIRC) under IG 2017-ID. 20353 project-P.I. Graziani Grazia.

\section{ORCID iD}

Ilaria Cacciotti (D) https://orcid.org/0000-0002-3478-6510

\section{References}

[1] Gil M I, Tomás-Barberán F A, Hess-Pierce B, Holcroft D M and Kader A A 2000 Antioxidant activity of pomegranate juice and its relationship with phenolic composition and processing J. Agric. Food Chem. 48 4581-9

[2] Määttä-Riihinen K R, Kamal-Eldin A and Törrönen A R 2004 Identification and quantification of phenolic compounds in berries of Fragaria and Rubus species (family rosaceae) J. Agric. Food Chem. 52 6178-87

[3] Li L, Tsao R, Yang R, Liu C, Zhu H and Young J C 2006 Polyphenolic profiles and antioxidant activities of heartnut (Juglans ailanthifolia Var. cordiformis) and Persian walnut (Juglans regia L.) J. Agric. Food Chem. 54 8033-40
[4] Goldberg D M, Hoffman B, Yang J and Soleas G J 1999 Phenolic constituents, furans, and total antioxidant status of distilled spirits J. Agric. Food Chem. 47 3978-85

[5] Landete J M 2012 Updated knowledge about polyphenols: functions, bioavailability, metabolism, and health Crit. Rev. Food Sci. Nutr. 52 936-48

[6] Vattem D A, Ghaedian R and Shetty K 2005 Enhancing health benefits of berries through phenolic antioxidant enrichment: focus on cranberry Asia Pac. J. Clin. Nutr. 14 120-30

[7] Ceci C et al 2016 Ellagic acid inhibits bladder cancer invasiveness and in vivo tumor growth Nutrients $\mathbf{8} 744$

[8] Ceci C, Lacal P, Tentori L, De Martino M, Miano R and Graziani G 2018 Experimental evidence of the antitumor, antimetastatic and antiangiogenic activity of ellagic acid Nutrients 101756

[9] Larrosa M, García-Conesa M T, Espín J C and Tomás-Barberán F A 2010 Ellagitannins, ellagic acid and vascular health Mol. Aspects Med. 31 513-39

[10] Porat Y, Abramowitz A and Gazit E 2006 Inhibition of amyloid fibril formation by polyphenols: structural similarity and aromatic interactions as a common inhibition mechanism Chem. Biol. Drug Des. 67 27-37

[11] Becker C G, Hajjar D P and Hefton J M 1985 Tobacco constituents are mitogenic for arterial smooth-muscle cells Am. J. Pathol. 120 1-5

[12] De R, Sarkar A, Ghosh P, Ganguly M, Karmakar B C, Saha D R, Halder A, Chowdhury A and Mukhopadhyay A K 2018 Antimicrobial activity of ellagic acid against Helicobacter pylori isolates from India and during infections in mice J. Antimicrob. Chemother. 73 1595-603

[13] Howell A B and D'Souza D H 2013 The pomegranate: effects on bacteria and viruses that influence human health Evidence Based Complement. Altern. Med. 2013606212

[14] Park S W, Kwon M J, Yoo J Y, Choi H-J and Ahn Y-J 2014 Antiviral activity and possible mode of action of ellagic acid identified in Lagerstroemia speciosa leaves toward human rhinoviruses BMC Complement. Altern. Med. 14171

[15] Morosetti G, Criscuolo A A, Santi F, Perno C F, Piccione E and Ciotti M 2017 Ellagic acid and Annona muricata in the chemoprevention of HPV-related pre-neoplastic lesions of the cervix Oncol. Lett. 13 1880-4

[16] Aguilar-Zarate P, Wong-Paz J E, Buenrostro-Figueroa J J, Ascacio J A, Contreras-Esquivel J C and Aguilar C N 2018 Ellagitannins: bioavailability, purification and biotechnological degradation Mini-Reviews Med. Chem. 18 1244-52

[17] Bala I, Bhardwaj V, Hariharan S and Kumar M N V R 2006 Analytical methods for assay of ellagic acid and its solubility studies J. Pharm. Biomed. Anal. 40 206-10

[18] Castonguay A, Boukharta M and Teel R 1998 Biodistribution of, antimutagenic efficacies in salmonella typhimurium of, and Inhibition of P450 activities by ellagic acid and one analogue Chem. Res. Toxicol. 11 1258-64

[19] Madrigal-Carballo S, Lim S, Rodriguez G, Vila A O, Krueger C G, Gunasekaran S and Reed J D 2010 Biopolymer coating of soybean lecithin liposomes via layer-by-layer self-assembly as novel delivery system for ellagic acid J. Funct. Foods 2 99-106

[20] Löwe J 1868 Ueber die Bildung von Ellagsäure aus Gallussäure J. Für. Prakt. Chemie. 103 464-71

[21] Wu S and Tian L 2017 Diverse phytochemicals and bioactivities in the ancient fruit and modern functional food pomegranate (Punica granatum) Molecules 221606

[22] Rossi M, Erlebacher J, Zacharias D E, Carrell H L and Iannucci B 1991 The crystal and molecular structure of 
ellagic acid dihydrate: a dietary anti-cancer agent Carcinogenesis 12 2227-32

[23] Clifford M N and Scalbert A 2000 Ellagitannins - nature, occurrence and dietary burden J. Sci. Food Agric. 80 1118-25

[24] J-1 R, Giner R, Marín M and Recio M 2018 A pharmacological update of ellagic acid Planta Med. 84 1068-93

[25] Vadhanam M V, Aqil F, Ravoori S and Rc G 2011 Bioavailability of ellagic acid/ellagitannins from black raspberry and pomegranate Proc. of the 102nd Annual Meeting of the American Association for Cancer Research (Apr 2-6) Orlando, FL. Philadelphia (PA): AACR Cancer Res 2011; 71(8Suppl):Abstract nr 4603

[26] Seeram N P, Lee R and Heber D 2004 Bioavailability of ellagic acid in human plasma after consumption of ellagitannins from pomegranate (Punica granatum L.) juice Clin. Chim. Acta. 348 63-68

[27] Stoner G D et al 2005 Pharmacokinetics of anthocyanins and ellagic acid in healthy volunteers fed freeze-dried black raspberries daily for 7 days J. Clin. Pharmacol. 45 1153-64

[28] Whitley A C, Stoner G D, Darby M V and Walle T 2003 Intestinal epithelial cell accumulation of the cancer preventive polyphenol ellagic acid-extensive binding to protein and DNA Biochem. Pharmacol. 66 907-15

[29] García-Villalba R, Beltrán D, Espín J C, Selma M V and Tomás-Barberán F A 2013 Time course production of urolithins from ellagic acid by human gut microbiota $J$. Agric. Food Chem. 61 8797-806

[30] Cerdá B, Periago P, Espín J C and Tomás-Barberán F A 2005 Identification of urolithin a as a metabolite produced by human colon microflora from ellagic acid and related compounds J. Agric. Food Chem. 53 5571-6

[31] Espín J C, González-Barrio R, Cerdá B, López-Bote C, Rey A I and Tomás-Barberán F A 2007 Iberian pig as a model to clarify obscure points in the bioavailability and metabolism of ellagitannins in humans J. Agric. Food Chem. 55 10476-85

[32] Tomás-Barberán F A, García-Villalba R, González-Sarrías A, Selma M V and Espín J C 2014 Ellagic acid metabolism by human gut microbiota: consistent observation of three urolithin phenotypes in intervention trials, independent of food source, age, and health status J. Agric. Food Chem. 62 6535-8

[33] Tomás-Barberán F A, González-Sarrías A, García-Villalba R, Núñez-Sánchez M A, Selma M V, García-Conesa M T and Espín J C 2017 Urolithins, the rescue of "old" metabolites to understand a "new" concept: metabotypes as a nexus among phenolic metabolism, microbiota dysbiosis, and host health status Mol. Nutr. Food Res. 611500901

[34] Alfei S, Turrini F, Catena S, Zunin P, Grilli M, Pittaluga A M and Boggia R 2019 Ellagic acid a multi-target bioactive compound for drug discovery in CNS? A narrative review Eur. J. Med. Chem. 183111724

[35] Ratnam D V, Ankola D D, Bhardwaj V, Sahana D K and Kumar M N V R 2006 Role of antioxidants in prophylaxis and therapy: a pharmaceutical perspective J. Control. Release 113 189-207

[36] Tiwari M K and Mishra P C 2013 Modeling the scavenging activity of ellagic acid and its methyl derivatives towards hydroxyl, methoxy, and nitrogen dioxide radicals $J$. Mol. Model 19 5445-56

[37] Mira L, Tereza Fernandez M, Santos M, Rocha R, Helena Florêncio M and Jennings K R 2002 Interactions of flavonoids with iron and copper ions: a mechanism for their antioxidant activity Free Radic. Res. 36 1199-208
[38] Craft B D, Kerrihard A L, Amarowicz R and Pegg R B 2012 Phenol-based antioxidants and the in vitro methods used for their assessment Compr. Rev. Food Sci. Food Saf. 11 148-73

[39] Srinivasan P, Vadhanam M, Arif J and Gupta R 2002 A rapid screening assay for antioxidant potential of natural and synthetic agents in vitro Int. J. Oncol. 20 983-6

[40] Teel R W, Martin R M and Allahyari R 1987 Ellagic acid metabolism and binding to DNA in organ explant cultures of the rat Cancer Lett. 36 203-11

[41] Thulstrup P W, Thormann T, Spanget-Larsen J and Bisgaard H C 1999 Interaction between ellagic acid and calf thymus DNA studied with flow linear dichroism UV-VIS spectroscopy Biochem. Biophys. Res. Commun. 265 416-21

[42] Mishra S and Vinayak M 2014 Ellagic acid inhibits PKC signaling by improving antioxidant defense system in murine T cell lymphoma Mol. Biol. Rep. 41 4187-97

[43] Ding Y, Wang L, Song J and Zhou S 2017 Protective effects of ellagic acid against tetrachloride-induced cirrhosis in mice through the inhibition of reactive oxygen species formation and angiogenesis Exp. Ther. Med. 14 3375-80

[44] Mo J, Panichayupakaranant P, Kaewnopparat N, Songkro S and Reanmongkol W 2014 Topical anti-inflammatory potential of standardized pomegranate rind extract and ellagic acid in contact dermatitis Phyther. Res. 28 629-32

[45] Yılmaz E E, Bozdağ Z, Ibiloğlu I, Arıkanoğlu Z, Üc Y, Kaplan I, Gümüş M and Atamanalp S S 2016 Therapeutic effects of ellagic acid on L-arginin induced acute pancreatitis Acta Cir. Bras. 31 396-401

[46] Masamune A, Satoh M, Kikuta K, Suzuki N, Satoh K and Shimosegawa T 2005 Ellagic acid blocks activation of pancreatic stellate cells Biochem. Pharmacol. 70 869-78

[47] Cornélio Favarin D, Martins Teixeira M, Lemos de Andrade E, de Freitas Alves C, Lazo Chica J E, Artério Sorgi C, Faccioli L H and Paula Rogerio A 2013 Anti-inflammatory effects of ellagic acid on acute lung injury induced by acid in mice Mediators Inflamm. 2013164202

[48] Marín M, María Giner R, J-1 R and Carmen Recio M 2013 Intestinal anti-inflammatory activity of ellagic acid in the acute and chronic dextrane sulfate sodium models of mice colitis J. Ethnopharmacol. 150 925-34

[49] Romier B, Van De Walle J, During A, Larondelle Y and Schneider Y-J 2008 Modulation of signalling nuclear factor- $\mathrm{kB}$ activation pathway by polyphenols in human intestinal Caco-2 cells Br. J. Nutr. 100 542-51

[50] Rosillo M A, Sánchez-Hidalgo M, Cárdeno A, Aparicio-Soto M, Sánchez-Fidalgo S, Villegas I and de la Lastra C A 2012 Dietary supplementation of an ellagic acid-enriched pomegranate extract attenuates chronic colonic inflammation in rats Pharmacol. Res. 66 235-42

[51] Zhou E, Fu Y, Wei Z and Yang Z 2014 Inhibition of allergic airway inflammation through the blockage of NF- $\kappa B$ activation by ellagic acid in an ovalbumin-induced mouse asthma model Food Funct. 52106

[52] Ahad A, Ganai A A, Mujeeb M and Siddiqui W A 2014 Ellagic acid, an NF- $\mathrm{KB}$ inhibitor, ameliorates renal function in experimental diabetic nephropathy Chem. Biol. Interact. 219 64-75

[53] Chun K S, Cha H H, Shin J W, Na H K, Park K K and Chung W Y 2003 Nitric oxide induces expression of cyclooxygenase-2 in mouse skin through activation of NF-kappaB Carcinogenesis 25 445-54

[54] El-Shitany N A, El-Bastawissy E A and El-desoky K 2014 Ellagic acid protects against carrageenan-induced acute inflammation through inhibition of nuclear factor kappa B, inducible cyclooxygenase and proinflammatory cytokines 
and enhancement of interleukin-10 via an antioxidant mechanism Int. Immunopharmacol. 19 290-9

[55] Papoutsi Z, Kassi E, Chinou I, Halabalaki M, Skaltsounis L A and Moutsatsou P 2008 Walnut extract (Juglans regia L.) and its component ellagic acid exhibit anti-inflammatory activity in human aorta endothelial cells and osteoblastic activity in the cell line KS483 Br. J. Nutr. 99 715-22

[56] Yu Y M, Wang Z H, Liu C H and Chen C S 2007 Ellagic acid inhibits IL-1 $\beta$-induced cell adhesion molecule expression in human umbilical vein endothelial cells Br. J. Nutr. $97692-8$

[57] Gubitosa J, Rizzi V, Fini P, Del Sole R, Lopedota A, Laquintana V, Denora N, Agostiano A and Cosma P 2020 Multifunctional green synthetized gold nanoparticles/chitosan/ellagic acid self-assembly: antioxidant, sun filter and tyrosinase-inhibitor properties Mat. Sci. Eng. C 106110170

[58] Murugan V, Mukherjee K, Maiti K and Mukherjee P K 2009 Enhanced oral bioavailability and antioxidant profile of ellagic acid by phospholipids J. Agric. Food Chem. 57 4559-65

[59] Li B, Harich K, Wegiel L, Taylor L S and Edgar K J 2013 Stability and solubility enhancement of ellagic acid in cellulose ester solid dispersions Carbohydr. Polym. 92 1443-50

[60] Kang I, Buckner T, Shay N F, Gu L and Chung S 2016 Improvements in metabolic health with consumption of ellagic acid and subsequent conversion into urolithins: evidence and mechanisms Adv. Nutr. 7 961-72

[61] Yan L, Yin P, Ma C and Liu Y 2014 Method development and validation for pharmacokinetic and tissue distributions of ellagic acid using ultrahigh performance liquid chromatography-tandem mass spectrometry (UPLC-MS/MS) Molecules 19 18923-35

[62] Lei F, Xing D-M, Xiang L, Zhao Y-N, Wang W, Zhang L-J and Du L-J 2003 Pharmacokinetic study of ellagic acid in rat after oral administration of pomegranate leaf extract $J$. Chromatogr. B. 796 189-94

[63] Seeram N P, Henning S M, Zhang Y, Suchard M, Li Z and Heber D 2006 Pomegranate juice ellagitannin metabolites are present in human plasma and some persist in urine for up to 48 hours J. Nutr. $1362481-5$

[64] Mertens-Talcott S U, Jilma-Stohlawetz P, Rios J, Hingorani L and Derendorf H 2006 Absorption, metabolism, and antioxidant effects of pomegranate (Punica granatum L.) polyphenols after ingestion of a standardized extract in healthy human volunteers J. Agric. Food Chem. 54 8956-61

[65] Bayle M, Roques C, Marion B, Audran M, Oiry C, Fmm B-G and Cros G 2016 Development and validation of a liquid chromatography-electrospray ionization-tandem mass spectrometry method for the determination of urolithin C in rat plasma and its application to a pharmacokinetic study J. Pharm. Biomed. Anal. 131 33-39

[66] Smart R C, Huang M-T, Chang R L, Sayer J M, Jerina D M and Conney A H 1986 Disposition of the naturally occurring antimutagenic plant phenol, ellagic acid, and its synthetic derivatives, 3 - O -decylellagic acid and 3, 3' -di$\mathrm{O}$-methylellagic acid in mice Carcinogenesis 7 1663-7

[67] David Josephy P, Lord H L and Snieckus V A 1990 Inhibition of benzo[a]pyrene dihydrodiol epoxide mutagenicity by synthetic analogues of ellagic acid Mutat. Res. Toxicol. 242 143-9

[68] Heur Y-H, Zeng W, Stoner G D, Nemeth G A and Hilton B 1992 Synthesis of ellagic acid o-alkyl derivatives and isolation of ellagic acid as a tetrahexanoyl derivative from fragaria ananassa J. Nat. Prod. 55 1402-7

[69] Kumar A, Tyagi Y K, Ponnan P, Rohil V, Prasad A K, Dwarkanath B S, Parmar V S and Raj H G 2007
Ellagic acid peracetate is superior to ellagic acid in the prevention of genotoxicity due to aflatoxin B 1 in bone marrow and lung cells J. Pharm. Pharmacol. 59 81-86

[70] Ren Y, Wei M, Still P C, Yuan S, Deng Y, Chen X, Himmeldirk K, Kinghorn A D and Yu J 2012 Synthesis and antitumor activity of ellagic acid peracetate ACS Med. Chem. Lett. 3 631-6

[71] Zhang H, Guo Z J, Xu W M, You X J, Han L, Han Y X and Dai L J 2014 Antitumor effect and mechanism of an ellagic acid derivative on the HepG2 human hepatocellular carcinoma cell line Oncol. Lett. 7 525-30

[72] González-Sarrías A, Giménez-Bastida J A, Má N-S, Larrosa M, García-Conesa M T, Tomás-Barberán F A and Espín J C 2014 Phase-II metabolism limits the antiproliferative activity of urolithins in human colon cancer cells Eur. J. Nutr. 53 853-64

[73] González-Sarrías A, Miguel V, Merino G, Lucas R, Morales J C, Tomás-Barberán F, Álvarez A I and Espín J C 2013 The gut microbiota ellagic acid-derived metabolite urolithin a and its sulfate conjugate are substrates for the drug efflux transporter breast cancer resistance protein (ABCG2/BCRP) J. Agric. Food Chem. 61 4352-9

[74] Ramírez de Molina A et al 2015 The ellagic acid derivative 4,4'-Di- O -methylellagic acid efficiently inhibits colon cancer cell growth through a mechanism involving WNT16 J. Pharmacol. Exp. Ther. 353 433-44

[75] Hariharan S, Bhardwaj V, Bala I, Sitterberg J, Bakowsky U and Ravi Kumar M N V 2006 Design of estradiol loaded PLGA nanoparticulate formulations: a potential oral delivery system for hormone therapy Pharm. Res. 23 184-95

[76] Tekade R K, Maheshwari R and Tekade M 2017 Biopolymer-based nanocomposites for transdermal drug delivery Biopolymer-Based Composites Jana S, Maiti S, Jana S (eds) (Cambridge: Woodhead Publishing) pp 81-106

[77] Tekade R K, Maheshwari R, Soni N, Tekade M and Chougule M B 2017 Nanotechnology for the development of nanomedicine Nanotechnology-based Approaches for Targeting and Delivery of Drugs and Genes Mishra V, Kesharwani P, Cairul M, Amin M, Iyer A (eds) (Cambridge, MA: Academic Press) pp 3-61

[78] Cacciotti I et al 2018 Controlled release of 18- $\beta$ -glycyrrhetic acid by nanodelivery systems increases cytotoxicity on oral carcinoma cell line Nanotechnology 29285101

[79] Cacciotti I, Ciocci M, Di Giovanni E, Nanni F and Melino S 2018 Hydrogen sulfide-releasing fibrous membranes: potential patches for stimulating human stem cells proliferation and viability under oxidative stress Int. J. Mol. Sci. 19 E2368

[80] Jeong Y-I, Y $\bar{v}$ R P, Ohno T, Yoshikawa Y, Shibata N, Kato S, Takeuchi K and Takada K 2001 Application of Eudragit $\mathrm{P}-4135 \mathrm{~F}$ for the delivery of ellagic acid to the rat lower small intestine J. Pharm. Pharmacol. 53 1079-85

[81] Ogawa Y, Kanatsu K, Iino T, Kato S, Jeong Y, Shibata N, Takada K and Takeuchi K 2002 Protection against dextran sulfate sodium-induced colitis by microspheres of ellagic acid in rats Life Sci. 71 827-39

[82] Wang H, Zhang Y, Tian Z, Ma J, Kang M, Ding C and Ming D 2017 Preparation of $\beta$-CD-ellagic acid microspheres and their effects on HepG2 cell proliferation Molecules 222175

[83] Bala I, Bhardwaj V, Hariharan S, Sitterberg J, Bakowsky U and Kumar M N V R 2005 Design of biodegradable nanoparticles: a novel approach to encapsulating poorly soluble phytochemical ellagic acid Nanotechnology 16 2819-22 
[84] Arulmozhi V, Pandian K and Mirunalini S 2013 Ellagic acid encapsulated chitosan nanoparticles for drug delivery system in human oral cancer cell line (KB) Colloids Surf. B $110313-20$

[85] Sharma G, Italia J L, Sonaje K, Tikoo K and Kumar M N V R 2007 Biodegradable in situ gelling system for subcutaneous administration of ellagic acid and ellagic acid loaded nanoparticles: evaluation of their antioxidant potential against cyclosporine induced nephrotoxicity in rats J. Control Release 118 27-37

[86] Sonaje K, Italia J L, Sharma G, Bhardwaj V, Tikoo K and Kumar M N V R 2007 Development of biodegradable nanoparticles for oral delivery of ellagic acid and evaluation of their antioxidant efficacy against cyclosporine A-induced nephrotoxicity in rats Pharm. Res. 24 899-908

[87] Ratnam D V, Chandraiah G, Meena A K, Ramarao P and Kumar M N V R 2009 The co-encapsulated antioxidant nanoparticles of ellagic acid and coenzyme $\mathrm{Q}_{10}$ ameliorates hyperlipidemia in high fat diet fed rats $J$. Nanosci. Nanotechnol. $96741-6$

[88] Shirode A B, Bharali D J, Nallanthighal S, Coon J K, Mousa S A and Reliene R 2015 Nanoencapsulation of pomegranate bioactive compounds for breast cancer chemoprevention Int. J. Nanomedicine 10 475-84

[89] Barnaby S N, Yu S M, Tsiola A, Fath K R and Banerjee I A $2011 \mathrm{pH}$ dependent spontaneous growth of ellagic acid assemblies for targeting HeLa cells $J$. Nanosci. Nanotechnol. 11 7579-86

[90] Dubey A, Park D W, Kwon J E, Jeong Y J, Kim T, Kim I, Kang S C and Chi K W 2015 Investigation of the biological and anti-cancer properties of ellagic acid-encapsulated nano-sized metalla-cages Int. $J$. Nanomedicine 10 227-40

[91] Hussein M Z, Al Ali S H, Zainal Z and Hakim M N 2011 Development of antiproliferative nanohybrid compound with controlled release property using ellagic acid as the active agent Int. J. Nanomedicine 6 1373-83

[92] Behl G, Sharma M, Dahiya S, Chhikara A and Chopra M 2011 Synthesis, characterization, and evaluation of radical scavenging ability of ellagic acid-loaded nanogels $J$. Nanomater. 2011 1-9

[93] Bala I, Bhardwaj V, Hariharan S, Kharade S V, Roy N and Kumar M N V R 2006 Sustained release nanoparticulate formulation containing antioxidant-ellagic acid as potential prophylaxis system for oral administration $J$. Drug Target 14 27-34

[94] Wei Y, Wang Y, Xia D, Guo S, Wang F, Zhang X and Gan Y 2017 Thermosensitive liposomal codelivery of HSA-paclitaxel and HSA-ellagic acid complexes for enhanced drug perfusion and efficacy against pancreatic cancer ACS Appl. Mater. Interfaces $925138-51$

[95] Bulani V D, Kothavade P S, Kundaikar H S, Gawali N B, Chowdhury A A, Degani M S and Juvekar A R 2016 Inclusion complex of ellagic acid with $\beta$-cyclodextrin: characterization and in vitro anti-inflammatory evaluation J. Mol. Struct. 1105 308-15

[96] Junyaprasert V B, Singhsa P and Jintapattanakit A 2013 Influence of chemical penetration enhancers on skin permeability of ellagic acid-loaded niosomes Asian J. Pharm. Sci. 8 110-7

[97] Alfei S, Turrini F, Catena S, Zunin P, Parodi B, Zuccari G, Pittaluga A M and Boggia R 2019 Preparation of ellagic acid micro and nano formulations with amazingly increased water solubility by its entrapment in pectin or non-PAMAM dendrimers suitable for clinical applications New J. Chem. 43 2438-48
[98] Abd-Rabou A A and Ahmed H H 2017 CS-PEG decorated PLGA nano-prototype for delivery of bioactive compounds: A novel approach for induction of apoptosis in HepG2 cell line Adv. Med. Sci. 62 357-67

[99] Liu Z, Jiao Y, Wang Y, Zhou C and Zhang Z 2008 Polysaccharides-based nanoparticles as drug delivery systems Adv. Drug Deliv. Rev. 60 1650-62

[100] Shahidi F, Arachchi J K V and Jeon Y-J 1999 Food applications of chitin and chitosans Trends Food Sci. Technol. 10 37-51

[101] Bala I, Hariharan S and Kumar M N V R 2004 PLGA nanoparticles in drug delivery: the state of the art Crit. Rev. Ther. Drug Carrier Syst. 21 287-422

[102] Bhardwaj V, Hariharan S, Bala I, Lamprecht A, Kumar N, Panchagnula R and Kumar M N V R 2006 Pharmaceutical aspects of polymeric nanoparticles for oral drug delivery $J$. Biomed. Nanotechnol. $1235-58$

[103] Arbós P, Campanero M A, Arangoa M A and Irache J M 2004 Nanoparticles with specific bioadhesive properties to circumvent the pre-systemic degradation of fluorinated pyrimidines J. Control Release 96 55-65

[104] Gopalakrishnan L, Ramana L N, Sethuraman S and Krishnan U M 2014 Ellagic acid encapsulated chitosan nanoparticles as anti-hemorrhagic agent Carbohydr. Polym. 111 215-21

[105] Mirunalini S, Arulmozhi V and Isabella S 2017 Chemotherapeutic effect of ellagic acid encapsulated chitosan nanoparticles on DMBA induced hamster buccal pouch carcinogenesis J. Chem. Pharm. Sci. 10 963-71

[106] Pirzadeh-Naeeni S, Mozdianfard M R, Shojaosadati S A, Khorasani A C and Saleh T 2020 A comparative study on schizophyllan and chitin nanoparticles for ellagic acid delivery in treating breast cancer Int. J. Biol. Macromol. 144 380-8

[107] Luján-Medina G A, Ventura J, Ascacio-Valdés J A, Cerqueira M A, Villa D B, Contreras-Esquivel J C, Aguilar Gonzãlez M A, Vicente A and Aguilar C N 2015 Microencapsulation of ellagic acid from pomegranate husk and karaya gum by spray drying Int. J. Pharm. Pharm. Sci. 7 212-6

[108] Suri S, Mirza M A, Anwer M K, Alshetaili A S, Alshahrani S M, Ahmed F J and Iqbal Z 2019 Development of NIPAAm-PEG acrylate polymeric nanoparticles for co-delivery of paclitaxel with ellagic acid for the treatment of breast cancer J. Pol. Eng. 39 271-8

[109] Mady F and Shaker M 2017 Enhanced anticancer activity and oral bioavailability of ellagic acid through encapsulation in biodegradable polymeric nanoparticles Int. J. Nanomedicine 12 7405-17

[110] Kim S, Nishimoto S K, Bumgardner J D, Haggard W O, Gaber M W and Yang Y 2010 A chitosan/ $\beta$-glycerophosphate thermo-sensitive gel for the delivery of ellagic acid for the treatment of brain cancer Biomaterials 31 4157-66

[111] Boukharta M, Jalbert G and Castonguay A 1992 Biodistribution of ellagic acid and dose-related inhibition of lung tumorigenesis in A/J mice Nutr. Cancer 18 181-9

[112] Chudasama Y N, Lugea A, Lu Q Y and Pandol S J 2011 Beta-cyclodextrin increases bioavailability of ellagic acid in rats Gastroenterology 140 S-860

[113] Bulani V, Kothavade P, Nagmoti D and Juvekar A 2014 Ellagic acid hydroxypropyl-ß-cyclodextrin inclusion complex alleviates adjuvant-induced arthritis: attenuation of oxidative stress and inflammatory mediators Cytokine 7032

[114] Bulani V D, Kothavade P S, Nagmoti D M, Kundaikar H S, Degani M S and Juvekar A R 2015 Characterisation and anti-inflammatory evaluation of the inclusion complex of 
ellagic acid with hydroxypropyl- $\beta$-cyclodextrin $J$. Incl. Phenom. Macrocycl. Chem. 82 361-72

[115] Savic I M, Jocic E, Nikolic V D, Popsavin M M, Rakic S J and Savic-Gajic I M 2019 The effect of complexation with cyclodextrins on the antioxidant and antimicrobial activity of ellagic acid Pharm. Dev. Technol. 24 410-8

[116] Beshbishy A M, Batiha G E S, Yokoyama N and Igarashi I 2019 Ellagic acid microspheres restrict the growth of Babesia and Theileria in vitro and Babesia microti in vivo Parasit. Vectors 12269

[117] Fan G, Cai Y, Fu E, Yuan X, Tang J, Sheng H and Gong J 2019 Preparation and process optimization of pomegranate ellagic acid-hydroxypropyl-b-cyclodextrin inclusion complex and its antibacterial activity in vitro Acta Med. Mediterr. 35 383-9

[118] Laye C, McClements D J and Weiss J 2008 Formation of biopolymer-coated liposomes by electrostatic deposition of chitosan J. Food Sci. 73 N7-15

[119] Stojiljković N, Ilić S, Stojanović N, Janković-Veličković L, Stojnev S, Kocić G, Radenković G, Arsić I, Stojanović M and Petković M 2019 Nanoliposome-encapsulated ellagic acid prevents cyclophosphamide-induced rat liver damage Mol. Cell. Biochem. 458 185-95

[120] Junyaprasert V B, Singhsa P, Suksiriworapong J and Chantasart D 2012 Physicochemical properties and skin permeation of Span 60/Tween 60 niosomes of ellagic acid Int. J. Pharm. 423 303-11

[121] Taylor T M, Weiss J, Davidson P M and Bruce B D 2005 Liposomal nanocapsules in food science and agriculture Crit. Rev. Food Sci. Nutr. 45 587-605

[122] Gregoriadis G, Saffie R and De Souza J B 1997 Liposome-mediated DNA vaccination FEBS Lett. 402 107-10

[123] Maheshwari R G, Thakur S, Singhal S, Patel R P, Tekade M and Tekade R K 2015 Chitosan encrusted nonionic surfactant based vesicular formulation for topical administration of ofloxacin Sci. Adv. Mat. 7 1163-76

[124] Uchegbu I F and Vyas S P 1998 Non-ionic surfactant based vesicles (niosomes) in drug delivery Int. J. Pharm. $17233-70$

[125] Arunothayanun P, Turton J A, Uchegbu I F and Florence A T 1999 Preparation and in vitro/in vivo evaluation of luteinizing hormone releasing hormone (LHRH)-loaded polyhedral and spherical/tubular niosomes J. Pharm. Sci. 88 34-38

[126] Fang J Y, Yu S Y, Wu P C, Bin Huang Y and Tsai Y H 2001 In vitro skin permeation of estradiol from various proniosome formulations Int. J. Pharm. 215 91-99

[127] Manconi M, Sinico C, Valenti D, Loy G and Fadda A M 2002 Niosomes as carriers for tretinoin. I. Preparation and properties Int. J. Pharm. 234 237-48

[128] Tavano L, Alfano P, Muzzalupo R and De Cindio B 2011 Niosomes vs microemulsions: new carriers for topical delivery of Capsaicin Colloids Surf. B 87 333-9

[129] Konno H, Handa T, Alonzo D E and Taylor L S 2008 Effect of polymer type on the dissolution profile of amorphous solid dispersions containing felodipine Eur. J. Pharm. Biopharm. 70 493-9

[130] Qian F, Huang J and Hussain M A 2010 Drug-polymer solubility and miscibility: stability consideration and practical challenges in amorphous solid dispersion development J. Pharm. Sci. 99 2941-7

[131] Dinunzio J C, Miller D A, Yang W, McGinity J W and Williams R O 2008 Amorphous compositions using concentration enhancing polymers for improved bioavailability of itraconazole Mol. Pharm. 5 968-80

[132] Friesen D T, Shanker R, Crew M, Smithey D T, Curatolo W J and Nightingale J A S 2008 Hydroxypropyl methylcellulose acetate succinate-based spray-dried dispersions: an overview Mol. Pharm. 5 1003-19

[133] Posey-Dowty J D, Watterson T L, Wilson A K, Edgar K J, Shelton M C and Lingerfelt L R 2007 Zero-order release formulations using a novel cellulose ester Cellulose $1473-83$

[134] Shelton M C, Posey-Dowty J D, Lingerfelt L, Kirk S K, Klein S and Edgar K J 2010 Enhanced dissolution of poorly soluble drugs from solid dispersions in carboxymethylcellulose acetate butyrate matrices Polysaccharide Materials: Performance by Design, ed K J Edgar, T Heinze and T Liebert (Washington, DC: American Chemical Society) pp 93-113

[135] Ilevbare G A, Liu H, Edgar K J and Taylor L S 2012 Inhibition of solution crystal growth of ritonavir by cellulose polymers - factors influencing polymer effectiveness Cryst. Eng. Comm. 146503

[136] Ilevbare G A, Liu H, Edgar K J and Taylor L S 2012 Understanding polymer properties important for crystal growth inhibition-impact of chemically diverse polymers on solution crystal growth of ritonavir Cryst. Growth Des. 12 3133-43

[137] Kar N, Liu H and Edgar K J 2011 Synthesis of cellulose adipate derivatives Biomacromolecules $\mathbf{1 2}$ 1106-15

[138] Liu H, Kar N and Edgar K J 2012 Direct synthesis of cellulose adipate derivatives using adipic anhydride Cellulose 19 1279-93

[139] Montes A, Wehner L, Pereyra C and Martínez de la Ossa E J 2016 Generation of microparticles of ellagic acid by supercritical antisolvent process J. Supercrit. Fluids. 116 101-10

[140] Li Y, Zhao X, Zu Y, Zhang Y, Ge Y, Zhong C and Wu W 2015 Preparation and characterization of micronized ellagic acid using antisolvent precipitation for oral delivery Int. J. Pharm. 486 207-16

[141] Avachat A M and Patel V G 2015 Self nanoemulsifying drug delivery system of stabilized ellagic acid-phospholipid complex with improved dissolution and permeability Saudi Pharm. J. 23 276-89

[142] Wang S T, Chou C T and Su N W 2017 A food-grade self-nanoemulsifying delivery system for enhancing oral bioavailability of ellagic acid J. Funct. Foods. 34 207-15

[143] Zheng D, Lv C, Sun X, Wang J and Zhao Z 2019 Preparation of a supersaturatable self-microemulsion as drug delivery system for ellagic acid and evaluation of its antioxidant activities J. Drug Del. Sci. Tech. 53101209

[144] Alfaifi M Y, Elbehairi S, Shati A A, Fahmy U A, Alhakamy N A and Shadab M 2020 Ellagic acid loaded TPGS micelles for enhanced anticancer activities in ovarian cancer Int. J. Pharm. 16 63-71

[145] Abd Elwakil M M, Mabrouk M T, Helmy M W, Abdelfattah E Z A, Khiste S K, Elkhodairy K A and Elzoghby A O 2018 Inhalable lactoferrin-chondroitin nanocomposites for combined delivery of doxorubicin and ellagic acid to lung carcinoma Nanomedicine $132015-35$

[146] Hajipour H, Hamishehkar H, Rahmati-Yamchi M, Shanehbandi D, Ahmad S N S and Hasani A 2018 Enhanced anti-cancer capability of ellagic acid using solid lipid nanoparticles (SLNs) Int. J. Cancer Man. 11 e9402

[147] Aldawsari H M and Hosny K M 2018 Solid lipid nanoparticles of Vancomycin loaded with Ellagic acid as a tool for overcoming nephrotoxic side effects: preparation, characterization, and nephrotoxicity evaluation J. Drug Del. Sci. Tech. 45 76-80 
[148] Li Z, Tan S, Li S, Shen Q and Wang K 2017 Cancer drug delivery in the nano era: an overview and perspectives Oncol. Rep. 38 611-24

[149] De Santis M and Cacciotti I 2020 Wireless implantable and biodegradable sensors for postsurgery monitoring: current status and future perspectives Nanotechnology 31252001
[150] Khan A N, Ermakov A, Sukhorukov G and Hao Y 2019 Radio frequency controlled wireless drug delivery devices Appl. Phys. Rev. 6041301

[151] Jones I et al 2008 Wireless RF communication in biomedical applications Smart Mater. Struct. 17015050 